\title{
The Rum Igneous Centre, Scotland
}

\author{
C. H. EMeleus ${ }^{1} *$ and V. R. TROLL ${ }^{2}$
}

1 Department of Earth Sciences, Durham University, Science Labs, South Road, Durham DH1 3LE, UK

2 Department of Earth Sciences, CEMPEG, Uppsala University, Villavägen 16, SE-752 36, Uppsala, Sweden

[Received 29 April 2013; Accepted March 2014; Associate Editor: F.C. Hawthorne]

\section{ABSTRACT}

The publication of the British Geological Survey memoir on Rum and the Small Isles in 1997 was followed by a period of intense petrological and mineralogical research, leading to some 40 papers, books and other publications. The research progress since then is reviewed here and integrated with the information previously available to provide an overview of the current status of understanding of the centre. New data on the acidic and mixed acid/basic magmas of the early Rum caldera demonstrate that frequent mafic replenishments were the main driver for magmatic activity at Rum right from its initial stages. The caldera is bound by the Main Ring Fault, a structure which probably also exercised an influence on the emplacement of the subsequent basic and ultrabasic intrusions. The later emplacement of gabbros and ultrabasic rocks caused only limited thermal metamorphism of the surrounding Torridonian sandstones, contrasting markedly with the crustal isotope signatures of the early intracaldera ignimbrite magmas and the intense alteration of uplifted masses of Lewisian gneiss within the ring fault. Rare picritic dykes provide an indication of the possible parent magma for the mafic and ultrabasic rocks, but these, as with most other magmatic rocks on Rum, have undergone varying degrees of crustal contamination, involving both Lewisian granulite and amphibolite-type crust but, notably, no Moine metasedimentary compositions as is the case at the nearby Ardnamurchan centre. Detailed textural studies on the gabbroic and ultrabasic rocks allow a distinction between intrusive peridotites and peridotite that forms part of the classic layered cumulate units of Rum and, furthermore, this work and that on the chromite seams and veins in these rocks shows that movement of trapped magma and magma derived from later intrusions, may produce textures regarded previously as of primary cumulate origin. Sulfides in the chromitite seams and ultrabasic rocks, in turn, show possible influences from assimilated Mesozoic sediments. Igneous activity on Rum was short-lived, possibly only between 0.5 and $1 \mathrm{~m}$.y. in duration and commenced at $\sim 60.5 \mathrm{Ma}$. The Rum Central Complex was extinct by the time the main activity at the nearby Skye Central Complex commenced ( $\sim 59 \mathrm{Ma})$. From recent apatite fission-track studies it seems probable that Rum, in common with other Palaeogene centres, underwent a brief, but significantly later heating event $(\sim 45 \mathrm{Ma})$.

KEYWORDs: mixed acid/basic magmas, gabbro, ultrabasic rocks, picrite, layered igneous cumulates, chromite, Rum, Scotland.

\section{Introduction}

THE Rum Palaeogene Central Complex, northwest Scotland, forms the hills of the Rum Cuillin and their immediate surroundings (Fig. 1) and its evolution is summarized in Table 1 . The Central

* E-mail: valentin.troll@geo.uu.se

DOI: $10.1180 /$ minmag.2014.078.4.04
Complex consists of an exceptionally well exposed suite of ultrabasic, basic and gabbroic rocks and granitic intrusions accompanied by rhyolitic and rhyodacitic intrusions and extrusives in a dissected caldera, all emplaced into sandstones of the Neoproterozoic Torridon Group. The majority of the igneous rocks are enclosed within a $12 \mathrm{~km}$ elliptical ring fault (the 'Main Ring Fault', MRF), with remnants of an early felsic stage of 

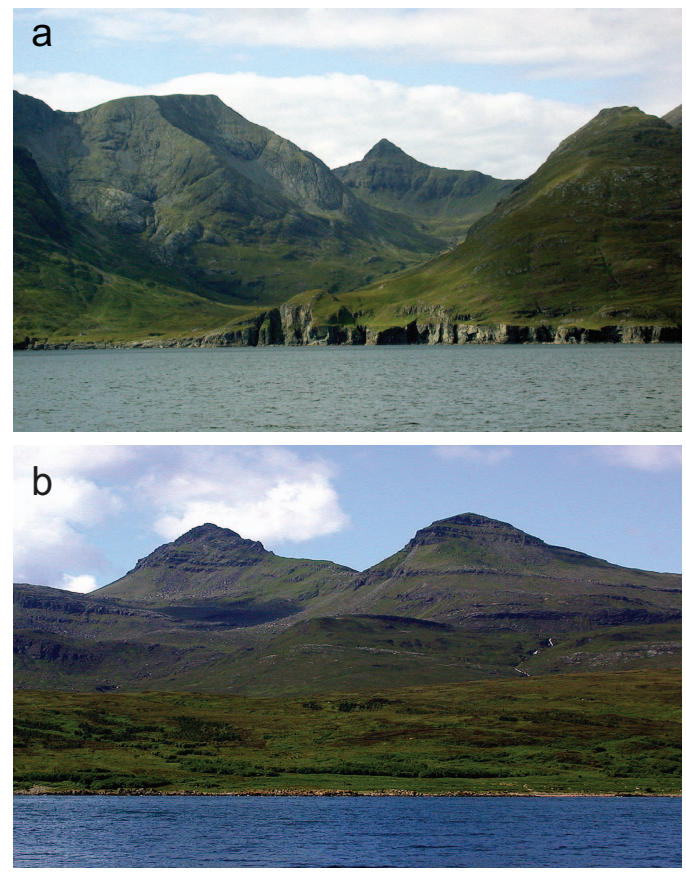

FIG. 1. (a) The eastern facing skyline of the Rum Cuillin (Glen Dibidil) viewed from the Sound of Rum. The hill on the left is Ainshval, the central peak is Trollaval and the hill to the right is Beinn nan Stac. Ainshval and Beinn nan Stac form part of the Southern Mountains Zone (SMZ). Rhyodacite ignimbrite sheets and sedimentary breccias make up the back wall of Nameless Coire and the Ainsval Ridge. Layered ultrabasic units in the Eastern Layered Intrusion (ELI) form the distinctive peak of Trollaval (far centre). Faulted Lewisian gneisses and Torridonian sandstones crop out along the foreshore to the right (see also Fig. 3). (b) Hallival and Askival, viewed from the Sound of Rum from the northeast. Torridonian sandstones crop out in the lower foreground. Note the distinct layering in the ultrabasic rocks and gabbro on the western face of Hallival.

volcanic activity (Stage 1, Table 1), cross-cut by basic and ultrabasic intrusions that comprise the famous Rum Layered Suite (Stage 2). During Stage 1, central uplift and subsidence on the arcuate MRF system was accompanied by acidic and mixed acid/basic magmatism and the subsequent formation of a caldera, which filled with acidic ash flows and breccias. Archaean Lewisian gneisses, rare occurrences of Mesozoic sedimentary rocks, the remnants of Palaeogene basaltic and intermediate lavas, as well as sedimentary rocks assigned to the lowermost members of the
Torridon Group (Table 1, Fig. 2a) are recorded within this early caldera. Volcanic activity commenced with the eruption of thick intracaldera rhyodacite ash-flow ignimbrites, fed from shallow-level intrusions located in close proximity to the MRF. The Western Granite also intruded at that time. Many of the acidic rocks of Stage 1 are of crustal origin with isotope signatures similar to those of the underlying Lewisian gneiss. Stage 2 commenced with the intrusion of basaltic cone sheets followed by the emplacement of the Ultrabasic Layered Suite that comprises predominantly feldspathic peridotites, troctolites and gabbros, divided into the Eastern Layered Intrusion (ELI), the Western Layered Intrusion (WLI) and the Central Intrusion. The olivine-rich ultrabasic rocks on Rum are virtually all feldspar bearing and are referred to indiscriminately as peridotite or feldspathic peridotite in the literature, peridotite is used here for brevity. In eastern and western Rum, these mafic and ultramafic rocks form prominent, gently inward-dipping layers (Fig. 1b). Central Rum comprises a north-south belt of igneous breccias (peridotites and troctolites) where a major north-south fault, the Long Loch Fault (LLF), bisects the Central Complex. The LLF has a history of pre- and post-Central Complex movement and probably played a crucial role during the emplacement of ultrabasic and gabbroic rocks. Indeed, it is regarded widely as the feeder system for the entire Layered Suite (McClurg, 1982; Volker and Upton, 1990; Emeleus et al., 1996). A major volcanic edifice was probably built over Rum during Stage 2, but subsequent erosion rapidly set in. In northwest Rum, the weathered surface of the Western Granite is overlain by basaltic lavas and fluvial conglomerates of the Canna Lava Formation (Emeleus, 1985). Inter-lava conglomerates contain clasts of rhyodacite, microgranite, troctolite and gabbro derived from the Rum Igneous Centre. Clasts derived from Rum have also been identified in conglomerates within lavas on Canna and Sanday and in southwest Skye (e.g. Emeleus, 1997; Emeleus and Troll, 2011), indicating that Rum was deeply dissected prior to the onset of the main igneous activity on Skye.

\section{History of geological investigation}

Following the pioneering investigations of J.W. Judd (e.g. Judd, 1874) and Sir Archibald Geikie (e.g. Geikie, 1897), the first comprehensive examination of the geology of Rum was by Alfred 
TABLE 1. Evolution of the Rum Central Igneous Complex.

\section{Pre-Palaeogene}

Lewisian gneisses (Amphibolite-facies) overlain by $>2.5 \mathrm{~km}$ of mid-Proterozoic Torridon Group sandstones and siltstones, a thin covering of lower Jurassic Broadford Beds (limestone, sandstone and siltstone) and Paleocene basaltic lavas of the Eigg Lava Formation, all intruded by dykes of the Muck swarm and the Rum sub-swarm. The Long Loch Fault was probably active well before the Palaeogene.

\section{Palaeogene Rum Central Igneous Complex: Stage 1}

Initiation of the MRF accompanied by major central uplift, with subsequent subsidence leading to caldera formation, the collapse of caldera walls and the formation of debris avalanche deposits, with concomitant intrusion and effusion of acidic and mixed acid/basic magmas and emplacement of the Am Màm intrusive breccia. Severe distortion of country rocks adjoining the MRF and collapse of major masses of country rocks off the rising dome, as at Welshmans Rock, etc. Emplacement of the Western Granite. Possible further central uplift on the MRF.

\section{Palaeogene Rum Central Igneous Complex: Stage 2}

Change to basaltic and ultrabasic magmatism, heralded by the intrusion of basaltic cone-sheets and dykes of the Rum sub-swarm, followed by emplacement of ultrabasic rocks and gabbros of the Central Intrusion, with construction of the Layered Suite (the Eastern and Western layered intrusions) through successive sheet-like injections of ultramafic and basaltic magmas from the Central Intrusion but ultimately supplied by feeders on the Long Loch Fault. Intrusion of numerous gabbro and peridotite plugs pre- and postdating the MRF. Further central uplift probably accompanied emplacement of Stage 2 as the Central Complex developed beneath a cover of earlier uplifted rocks (Stage 1 and pre-Palaeocene) and (contemporaneous?) lavas.

\section{Post Central Complex}

Immediately following the formation of the Central Complex, a succession of deep valleys developed during vigorous erosion of the Rum Volcano, becoming rapidly filled with coarse clastic debris (conglomerates, breccias) derived from the Central Complex and surroundings; these are interbedded with predominantly basaltic lavas belonging to the Canna Lava Formation (Palaeocene Skye Lava Group) which ponded against the flanks of the volcano. Some north to northwest-trending basalt dykes post-date the Canna Lava Formation but regional dykes were probably intruded throughout the Paleocene and a subsequent heating event (45 Ma) indicates that activity may have been prolonged.

Significant right-lateral movement on the Long Loch Fault postdates the Central Complex and Rum underwent further deep erosion by local glaciers and by ice from the Scottish mainland during the Pleistocene.

Harker (Harker, 1908), who mapped the Small Isles (Rum, Eigg, Muck and Canna) for the Geological Survey. For many years, Rum was a private sporting estate with strictly limited access. Few geologists visited and little research was carried out until the mid- $20^{\text {th }}$ century. On a brief visit during the 1940s, Bailey (1945) identified a major fault system, the MRF and noted that gneisses and the lowermost members of the Torridon Group only occur within the ring fault system, signifying a substantial central uplift. The gneisses were examined by Tilley (1944) and assigned to the Archaean Lewisian Complex. Several notable investigations took place during the ensuing decade. Brown (1956), for example, made a detailed study of the spectacularly layered ultrabasic rocks in eastern Rum (Fig. 1b), which contributed fundamentally to subsequent thinking on igneous cumulates (Wager et al., 1960; Wager and Brown, 1968). In the ELI a sequence of 15 major layers was recognized by Brown, each being designated a 'unit' (e.g. Unit 7) and Wadsworth (1961) established a stratigraphy for the layered ultrabasic and gabbroic rocks of the WLI, interpreting spectacular peridotite breccias as accumulations at the base of fault scarps in a magma chamber (see also Wadsworth, 1992). Around this time, the post-Central Complex age of the lavas in northwest Rum was demonstrated by Black (1952) while Hughes (1960) unravelled much of the detailed history of the pre-ultrabasic rhyodacitic extrusions and intrusions and accompanying breccias in southeast Rum (Figs 1a, 3, 4). Hughes demonstrated rheomorphic melting of high-silica rocks adjoining the mafic and ultrabasic intrusions (Fig. 11), which was followed by Dunham's investigation (Dunham, 1968), who carried out a detailed study of the rhyodacites 

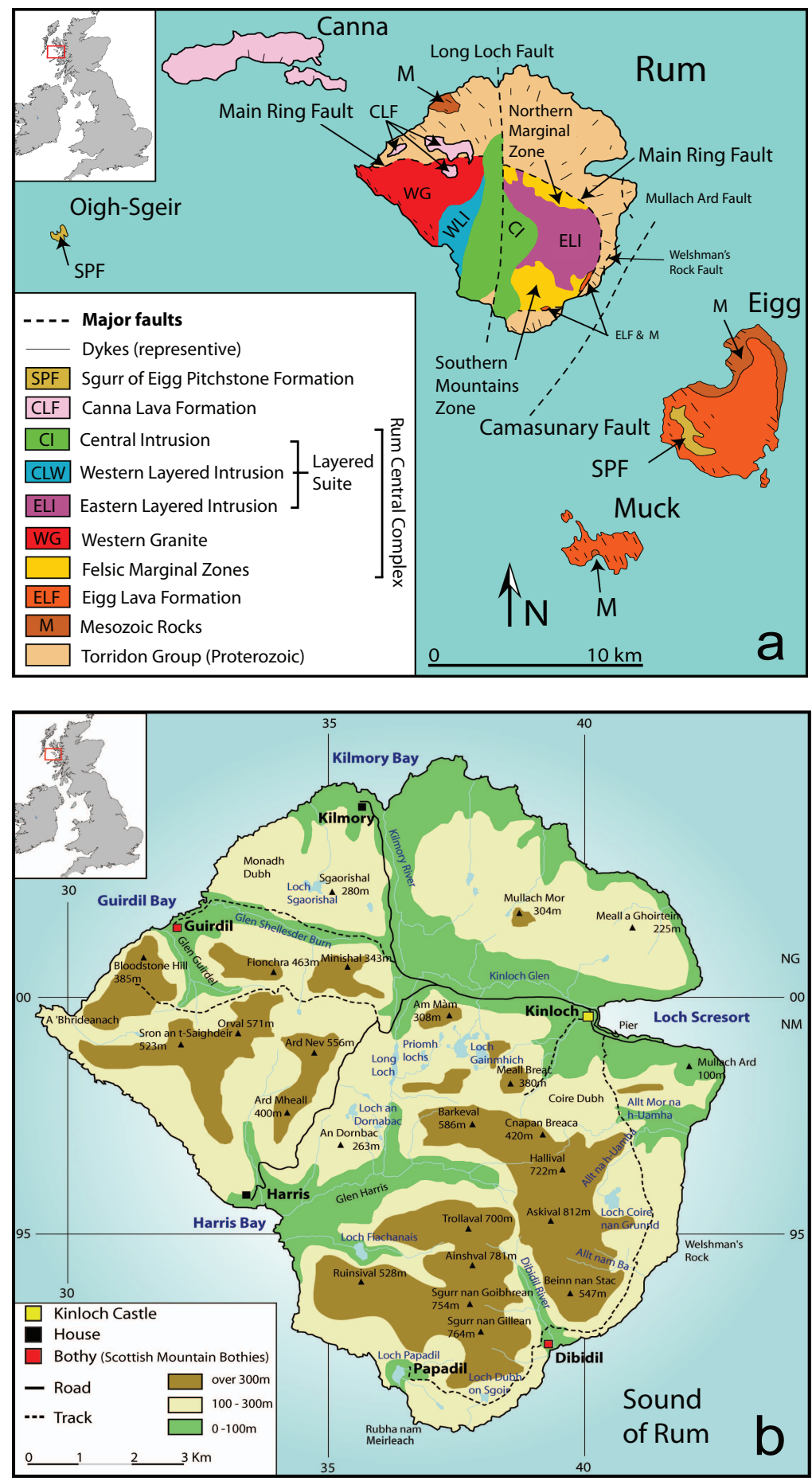

FIG. 2. (a) Simplified geological map of Rum and adjacent islands showing the major geological units. (b) Topographical sketch map of Rum with key localities indicated. 


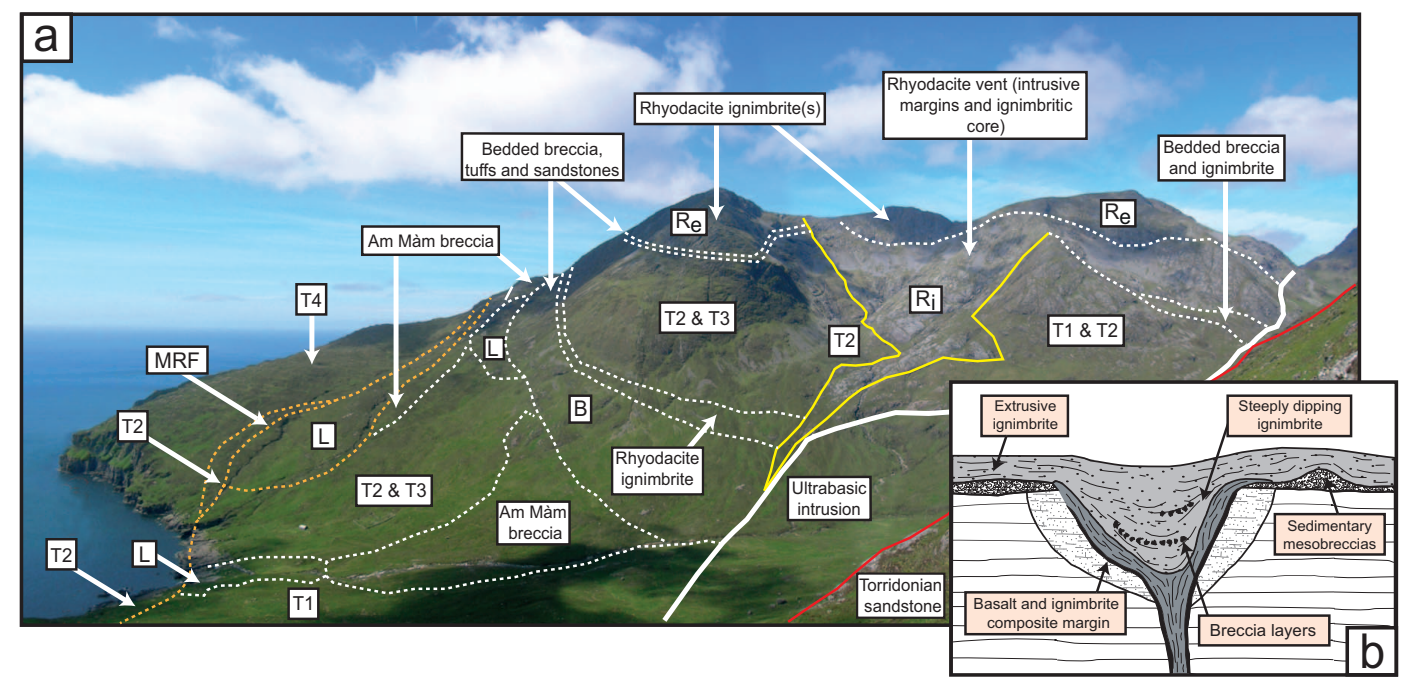

FIG. 3. (a) Panorama and geological outline of the lower southwest side of Glen Dibidil and the Sgurr nan Gillean-Ainshval Ridge, SMZ, viewed from the southeast side of Beinn nan Stac (see also Fig. 1a). L, Lewisian gneiss. Torridon Group: T1, Fiachanis Gritty Sandstone Member; T2, Laimhrig Shale Member; T3, Allt Mor na h-Uamha Member; T4, Sgor Mhor and Scresort sandstone members. Palaeocene: B, Bedded breccia, sandstone and tuff; Re, extrusive rhyodacite; Ri, intrusive rhyodacite; MRF Main Ring Fault. (modified after Holohan et al., in Emeleus and Troll, 2008). (b) Sketch showing the relationships between the rhyodacitic ignimbrite feeder, the caldera in-fill and the shattered caldera-floor rocks (after Holohan et al., 2009)

and associated breccias in the Northern Marginal Zone (NMZ) (Figs 2a, 5).

Rum was purchased by the Nature Conservancy Council (NCC; subsequently Scottish Natural Heritage - SNH) in 1957 and designated a National Nature Reserve (currently the largest Nature Reserve in the UK), whereupon access became less restricted and scientific research was actively encouraged. A succession of geological studies commenced at that point and these earlier investigations are summarized in the $2^{\text {nd }}$ edition of the British Geological Survey's Memoir: Geology of Rum and the Adjacent Islands (Emeleus, 1997) and are incorporated into the revised geological maps of Rum (Rum - Solid Geology; Scottish Natural Heritage, 1994) and Rum together with the adjacent islands (Rum; British Geological Survey, 1994). Subsequent research continued apace, with the publication of some 40 research papers, two reviews (Goodenough et al., 2008; Emeleus and Troll, 2011), a detailed field guide to the Palaeogene igneous rocks (Emeleus and Troll, 2008) and a new $\left(4^{\text {th }}\right)$ edition of the British Geological Survey's classic Tertiary (now Palaeogene) volcanic districts of Scotland (Emeleus and Bell,
2005). The current review is an attempt to assess the wider significance of the research that has become available in the last $15-20$ years since publication of the 1997 BGS Memoir.

\section{Recent research}

Notable advances in understanding the geology of Rum have been made in several fields since the publication of the 1997 Memoir. These advances have been achieved through the application of techniques ranging from classic field mapping and petrography to detailed textural studies and geochemical, geophysical and isotopic investigations and include: (1) the structure and volcanic stratigraphy of the early acidic rocks and associated breccias (Stage 1); (2) the recognition of the importance of 'mixed magmas' in the genesis of these rocks; (3) the role of crustal anatexis in the generation of the silicic magmas and the evidence of limited melting around the complex; (4) the importance of metasomatism and migration of residual magma in the evolution of the ultrabasic rocks (Stage 2); (5) the origin(s) of the chromitite and the occurrence and significance of Pt-group elements in the Rum Layered Suite; 


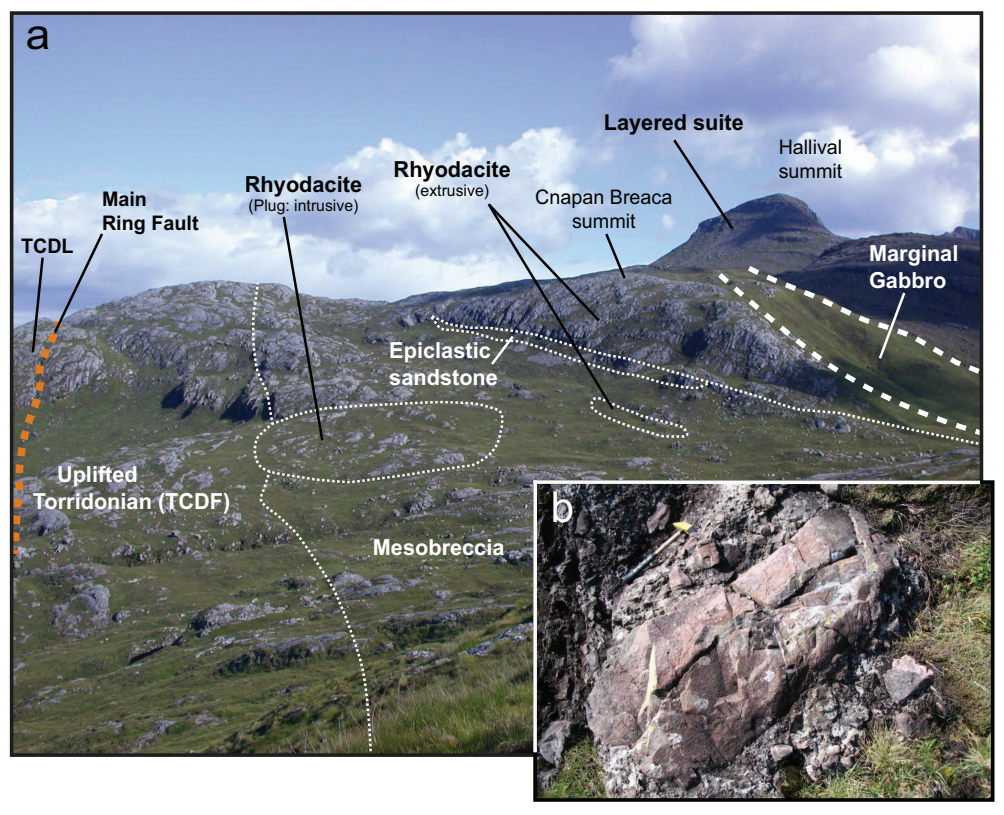

Fig. 4. (a) Panoramic view of the Northern Marginal Zone (NMZ) in the Coire Dubh area viewed from Meal Breac (from the northwest). Rocks of the NMZ form the low foreground (Coire Dubh Breccia) and the pale crags and outcrops on Cnapan Breaca (centre) are rhyodacite ash-flow deposits. The base of the crags on Cnapan Breaca marks the position of bedded tuffs and fine-grained sandstone. The easily weathered marginal gabbro of the ELI (Layered Suite) forms the grassy area on the right-hand flank of Cnapan Breaca. The terraced slopes leading up to Hallival mark the positions of troctolite ('allivalite') in layered units in the ELI. (b) Large angular block $(\sim 1 \mathrm{~m} \times 2 \mathrm{~m})$ of reddish Torridonian sandstone in finer Coire Dubh-type mesobreccia, SMZ. Hammer shaft is $\sim 45 \mathrm{~cm}$ long.

(6) the age and duration of the igneous activity at Rum.

\section{Structure and volcanic stratigraphy of early acidic rocks and associated breccias}

The extrusive and intrusive ignimbritic rhyodacites and the associated breccias, the Coire Dubh Breccias, of Stage 1, lie wholly within or on the MRF (Table 1; Figs 2a, 3, 4), which bounds a major caldera. The breccias and rhyodacite ignimbrites filled the caldera basin and 'flooded' the Torridonian sandstone caldera floor, a situation now exposed in the NMZ (Troll et al., 2000; Donaldson et al., 2001). A similar but more complex assemblage of breccias and rhyodacites forms the Southern Mountains Zone (SMZ) in southeast Rum (Figs $2 a, 3$ ), recording an intricate volcano-tectonic sequence involving central uplift, caldera-margin collapse and ignimbrite intrusion and eruption (Holohan et al., 2008, 2009; Brown et al., 2009). The Coire Dubh Breccias in both the NMZ and SMZ (Figs 4, 5, 6), were attributed originally to explosive activity that accompanied the rising rhyodacite magma, but the presence of sedimentary structures and tuffaceous beds within the breccias and eutaxitic structures in the silicic rocks (Fig. 7) of both areas (Troll et al., 2000, 2004; Holohan et al., 2009) demonstrate that they formed by debris avalanches from over-steepened caldera walls of dominantly Torridonian lithologies. The breccias became overlain by and to an extent interbedded with the rhyodacite ash flows that erupted during the peak magmatic activity of Stage 1. These high-silica magmas reached the surface along steep-sided feeders now represented by fiammebearing intrusive rhyodacite dykes and plugs near the MRF (Fig. 7) (e.g. Troll et al., 2000; 2004; Holohan et al., 2009).

Determination of the anisotropy of magnetic susceptibility (AMS) provides a sensitive measure of magnetic petrofabrics and thus potential information on the internal structure and emplacement of igneous intrusions. The Western Granite (Table 1) lacks any visible macroscopic or 

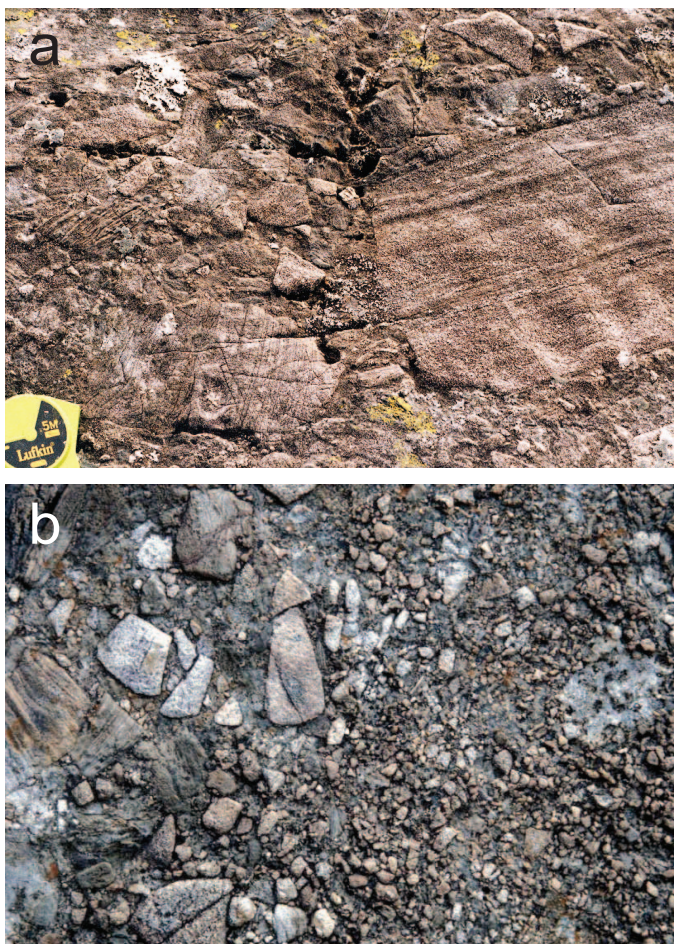

FIG. 5. (a) Coire Dubh Breccia with a chaotic assemblage of angular and sub-angular clasts mainly derived from the Torridonian Fiachanis Gritty Sandstone Member. Tape measure (bottom left) $\sim 8 \mathrm{~cm}$ across. (b) Plan view of shallow dipping Coire Dubh Breccia beds showing a coarser clast assemblage to the left than on the right, implying pulses of sediment accumulation within the caldera. Photograph is $\sim 40 \mathrm{~cm}$ across.

microscopic mineral alignment, but a distinct AMS fabric was mapped over the intrusion by Petronis et al. (2009). The AMS data indicate that the Western Granite may be the upper part of a high-level tabular sheet that was fed from the south or southeast and which was subsequently tilted by $\sim 15^{\circ}$ in a northwesterly direction during the intrusion of the later Layered Suite. Therefore, the Western Granite is clearly linked to Stage 1 of Rum's activity and probably represents the intrusive equivalent of the rhyodacite ignimbrites (e.g. Troll et al., 2004; Meyer et al., 2009; Petronis et al., 2009).

\section{The importance of 'mixed magmas'}

The close association of acidic and basic magmatism and the abundant evidence for
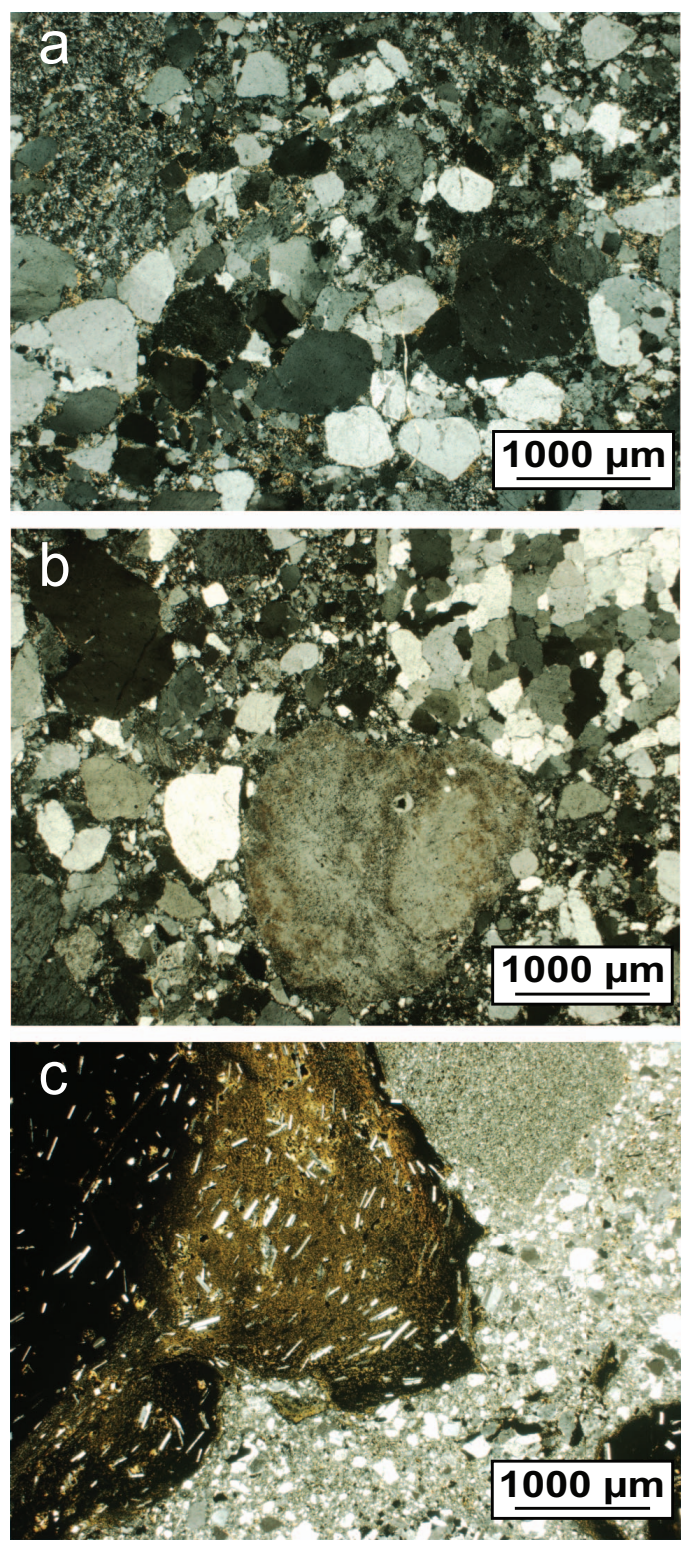

FIG. 6. $(a, b)$ Photomicrographs of fine-grained portions of Coire Dubh Breccia showing dominant quartz and potassium feldspar in a fine-grained matrix (crossed polarizers). (c) Basaltic chilled margin of a sheet intrusion against Coire-Dubh breccia (plane polarized light). Note the plagioclase microphenocryst alignment in the intrusion and the larger breccia clast in the top of the image.

'mixed magmas' is common throughout the British Palaeogene Igneous Province (e.g. Blake et al., 1965). The Rum rhyodacites provide 


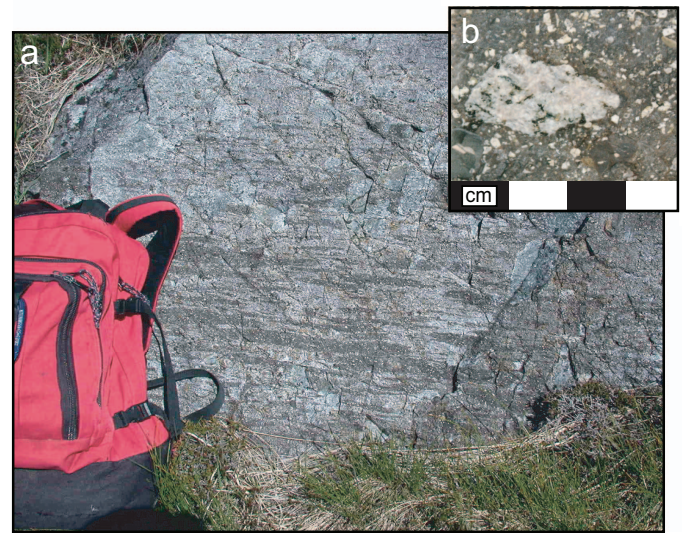

FIG. 7. (a) Attenuated fiamme in porphyritic rhyodacite ash-flow deposits, southwest end of Meall Breac, NMZ. The foliation defined by the fiamme points towards the centre of the caldera, implying flow from the caldera margin towards its interior. (b) Xenolith of Lewisian gneiss in rhyodacite $(\sim 3 \mathrm{~cm}$ across $)$, Meall Breac.

convincing evidence of the role of mixed magmas in both the NMZ and SMZ (Fig. 8), preserving a record of chamber replenishment, blending of magmas and elemental exchange in the magma chamber, as well as physical mingling in the eruptive conduit (Troll et al., 2004). In addition to abundant evidence for mixed magmas in these early ignimbrites, the coeval to slightly earlier Am Màm intrusion breccia (Table 1, Figs $4 b, 8$ ) provides particularly compelling evidence of mixing and crustal anatexis (Meyer et al., 2009; Nicoll et al., 2009). The Am Màm breccia is wholly intrusive at the present erosion level and blocks and mega-blocks of coarse gabbro, rare peridotite, Lewissian gneiss and Torridonian sandstone attest to the disruption that accompanied the generation of this distinctive lithological unit (Fig. $9 a-d$ ). The Am Màm intrusion breccia is associated closely with the rhyodacites that cut and grade into it in the vicinity of the MRF and hosts abundant clasts, including blocks and megablocks of a very coarse-grained gabbro. Significantly, these coarse gabbro xenoliths are proof of deep basic magmatism prior to and during Stage 1 (Fig. 9b,h). The coarse grain size of the gabbro blocks and their well equilibrated mineral textures are an indication that these coarse gabbros were probably derived from a sizeable intrusion at depth (Nicoll et al., 2009), a conclusion in accord with the strongly contact- altered amphibolite (now a granular-textured pyroxene hornfels) and gneiss adjoining a chilled contact preserved in an exceptionally large gabbro megablock $(>200 \mathrm{~m}$ in diameter) just west of Am Màm hill (Emeleus and Troll, 2008) (Fig 9a,b). The Am Màm breccia's matrix (i.e. the liquids that hosted the mega-blocks) is compositionally highly variable (dacite to rhyodacite) with common plagioclase and pyroxene crystals. The Am Màm breccia also contains evidence for magma mixing in the form of frequent large xenocrysts (Fig. 9e), together with numerous small to medium-sized dark lobate microgranular enclaves that range in composition from basalt to trachyandesite (Fig. $9 c, d$ ).

\section{Crustal anatexis and the evidence of limited melting around the complex}

Geochemical and isotopic ( $\mathrm{Sr}, \mathrm{Nd}$ ) analysis of the intrusive rocks and Lewisian gneiss by Meyer et al. (2009) broadly underline the conclusion of Troll et al., (2004) that the rhyodacites were largely derived from partial melting of Lewisian gneisses $(>70 \%)$. Additionally, it was found that the sources were likely to have been amphibolitefacies gneisses (cf. Dickin and Jones, 1983) which may have undergone an earlier $\mathrm{Cs}$ and $\mathrm{Rb}$ depletion, without a discernible contribution from granulite-facies gneisses. This study corroborated that by Geldmacher et al. (2002) who also showed that, in contrast to Mull and Ardnamurchan, on Rum, there had been no contamination by Moinian metasedimentary rocks, which are characterized by extremely radiogenic isotope values in e.g. $\mathrm{Sr}$ and $\mathrm{Pb}$ when compared with the various Lewisian isotopic groups. The matrices of the Am Màm intrusion breccia show varying degrees of mixing between rhyolitic and basaltic endmembers in both the NMZ and SMZ. The coarse gabbro blocks and megablocks contained in the breccia record an isotope signal that indicates assimilation of up to $20 \%$ of the gneiss (Meyer et al., 2009; Nicoll et al., 2009), in contrast to the less contaminated gabbros and ultrabasic rocks emplaced during Stage 2. However, the dacite to rhyolite matrix of the Am Màm intrusion breccia requires between $\sim 40$ and $60 \%$ of a gneiss input (Fig. 10).

Isotopic evidence relevant to the crustal contamination history of the Layered Suite is provided by Tepley and Davidson's (2003) study of Sr-isotope distribution in individual cumulus plagioclase crystals from units 9 and 10 in the 

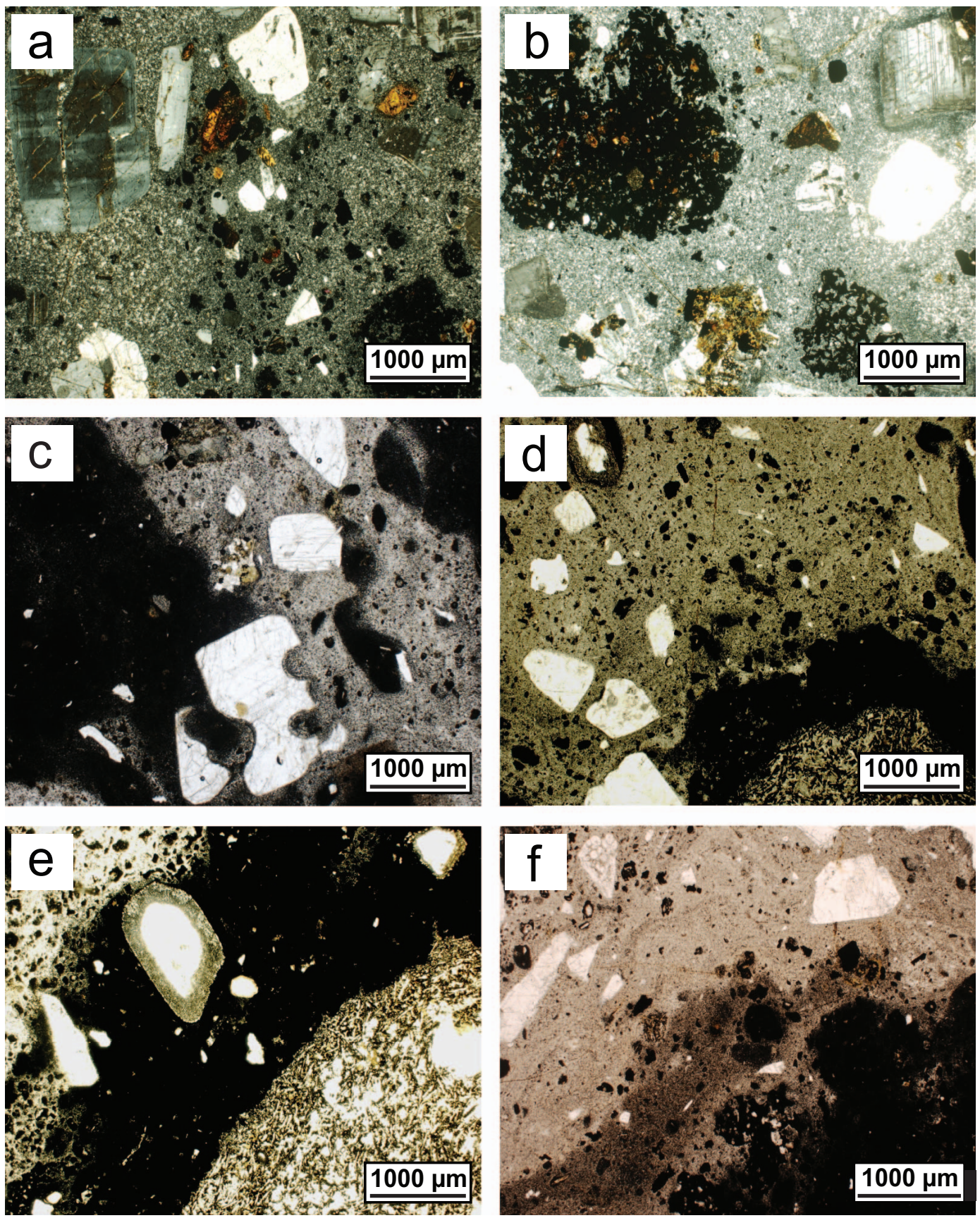

FIG. 8. $(a, b)$ Photomicrographs of porphyritic rhyodacite with magma mixing features. Fragments of plagioclase and broken and corroded $\beta$-quartz phenocrysts in a felsic matrix rich in small mafic inclusions ( $a$, crossed polarizers) and larger vesicular ones ( $b$, plane polarized light), Cnapan Breaca. ( $c-f$ ) Photomicrographs of magma mixing textures in a rhyodacite plug north of Cnapan Breaca (crossed polarizers). Note the resorbed plagioclase in (c) and the strong reaction rim on plagioclase inside a basic enclave in $(e)$. An example of emulsion texture, due to mixing between a rhyolite (top left, with crystals) and a basalt (bottom right), is shown in (f). 
C. H. EMELEUS AND V. R. TROLL
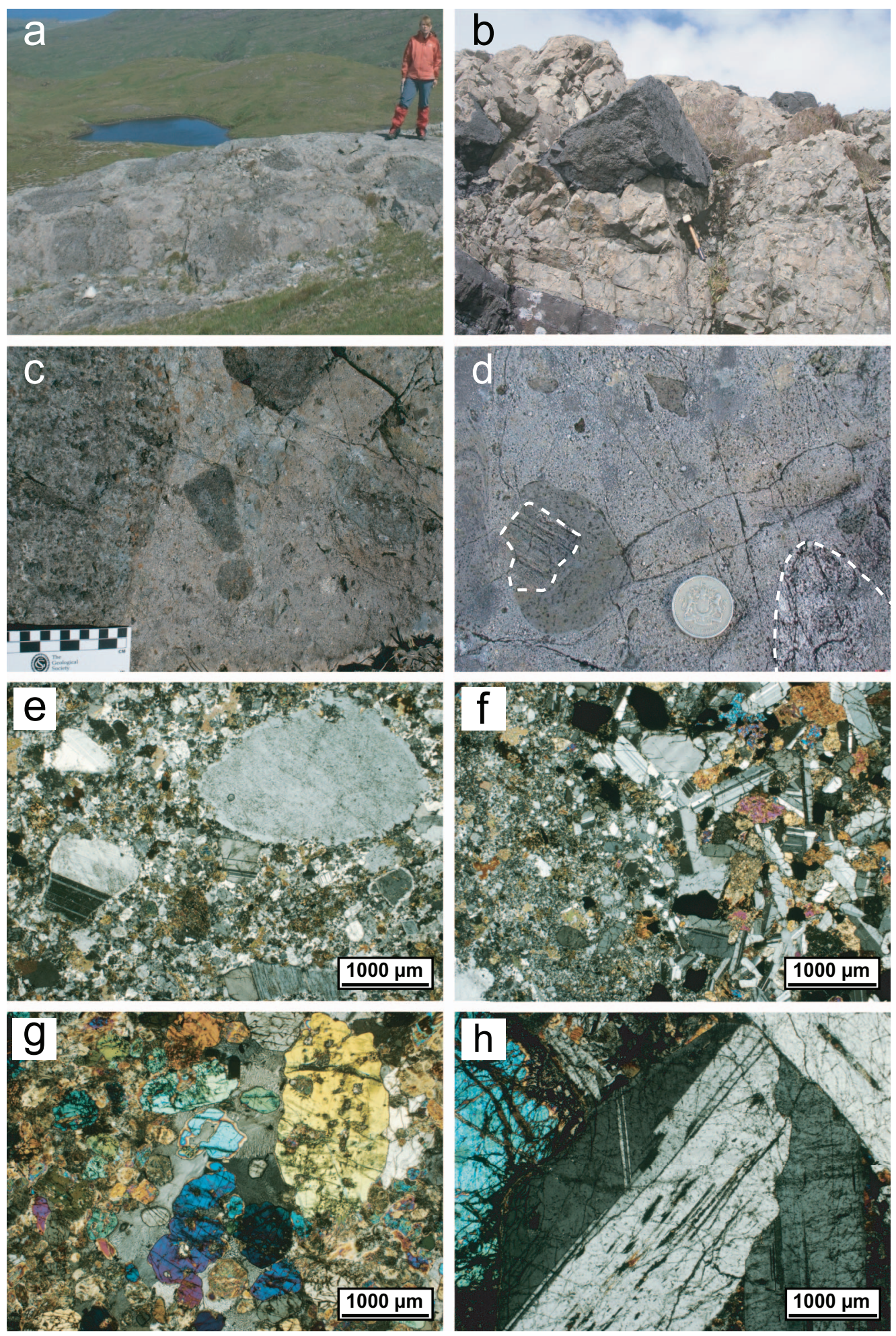
Eastern Layered Series (ELS). Large crystals (several $\mathrm{mm}$ ) were found to be isotopically heterogeneous whereas smaller ones were homogeneous. Crystals with contrasting isotopic signatures occur together and in Unit 9, the main focus of the investigation, individual large plagioclase crystals show increasingly contaminated signatures up section. Progressive aggregation of crystals with different contamination histories is envisaged. Cooling was probably sufficiently rapid to preclude attainment of isotopic equilibrium within and between crystals, which would require closure temperatures $\left(\sim 1000^{\circ} \mathrm{C}\right)$ being reached in a few thousand years and would be consistent with the layered rocks having formed from repeated small incremental replenishments.

While crustal contamination and anatexis were major factors during the magmatic evolution of the Rum Central Complex, extensive melting did not occur at the present erosion level where it is limited to within a few metres of the contacts. There is little isotopic evidence for e.g. assimilation of Torridonian sedimentary rocks (Geldmacher et al., 2002; Troll et al., 2004; Meyer et al., 2009) although these sedimentary rocks, together with leucocratic gneisses and early rhyodacite and microgranite are involved in spectacular intrusion breccias at contacts with the mafic intrusions in zones up to a few tens of metres wide (Fig. 11) (Emeleus and Troll, 2008, Excursions 2, 4b, 8, 9). Holness $(1999,2002)$ and Holness and Isherwood (2003) examined thermally altered Torridonian rocks at the contacts of gabbroic and peridotite plugs in Kinloch Glen and elsewhere in the complex. Up to $90 \%$ melting was noted in arkoses near a $50 \mathrm{~m}$ diameter gabbroic plug and distinctly less (70\%, up to $6 \mathrm{~m}$ from the margin) around a larger (200 $\mathrm{m}$ diameter) peridotite plug. Although locally extensive, as the melting was dependent on magma throughput in these plugs, the resulting high-silica melts were essentially static and did not move by significant distances as bedding in the host rock is not usually disrupted. Conspicuous $\mathrm{mm}$ - to $\mathrm{cm}$-scale spherulites are common in the thermally altered arkoses near such plugs, as are quartz paramorphs after tridymite (Fig. 12) (Holness, 2002). The spherulites (Fig. 12b) result from metastable crystallization of feldspar in radiating granophyric intergrowths. The tridymite provides a valuable clue as to possible temperatures and, importantly, indicates that the overburden was thin, possibly no more than $500 \mathrm{~m}$ (Holness, 1999; Holness and Winpenny, 2009). Only limited melting of Torridonian sandstone, trondhjemitic Lewisian gneiss and Palaeocene microgranite and rhyodacite is to be expected on Rum, because for melting to have been extensive in these relatively anhydrous, near-surface rocks, very high temperatures would have been required (cf. Holness, 2002). The more pronounced effects around some gabbro plugs were attributed to these acting as relatively long-lived conduits or feeder pipes to the surface, whereas the Kinloch Glen peridotite plug was regarded initially as a crystal mush when emplaced (Holness, 1999). A later study by Holness et al. (2012b) of the layered West Sgaorishal plug provided textural and structural evidence that this plug functioned initially as a long-lived conduit for olivine-rich magmas (see section below), becoming filled with olivine phenocrysts that settled out as the magma flow diminished and eventually ceased. Although lacking the spectacular layering of the West Sgaorishal plug, aligned tabular olivine pheno-

FIG. 9 (facing page). ( $a, b, c, d$ ) Representative portions of the Am Màm Breccia with characteristic coarse gabbro blocks on the north side of Am Màm hill $(a, c)$ and close to the northeast shore of Loch Gainmhich $(b)$. The dacitic matrix of the Am Màm Breccia contains a variety of lobate basic enclaves, sedimentary (Torridonian) as well as metamorphic (Lewisian) xenoliths. (d) Portion of the Am Màm intrusion breccia with a basic basaltic enclave containing a xenolith of bedded Torridonian sandstone (inside left-hand dashed line) and a larger fragment of Lewisian feldspathic gneiss (dashed line lower right-hand corner) north of Meall Breac. $(e-h)$ (all crossed polarizers): Photomicrographs of Am Màm breccia and inclusions. Quartz, augite and plagioclase in Am Màm Breccia plus a large rounded K-feldspar crystal that is probably foreign to this rock are shown in $(e)$. Augite and plagioclase xenocrysts and a disintegrating coarser-grained mafic xenolith in quartz-microdiorite matrix are shown in $(f)$. Thermally altered Lewisian xenolith in Am Màm intrusion breccia, with partial melting and recrystallization textures is shown in $(g)$. Coarse gabbro from a megablock near Loch Gainmich $(h)$. Nicoll et al. (2009) suggest these gabbros are amongst the 'deepest' rocks of the Rum pluton and were brought to this level by the Am Màm dacite magma that was probably forced into the active MRF during caldera collapse (Figs $9 b, d$ modified after Nicoll et al., 2009). 
C. H. EMELEUS AND V. R. TROLL
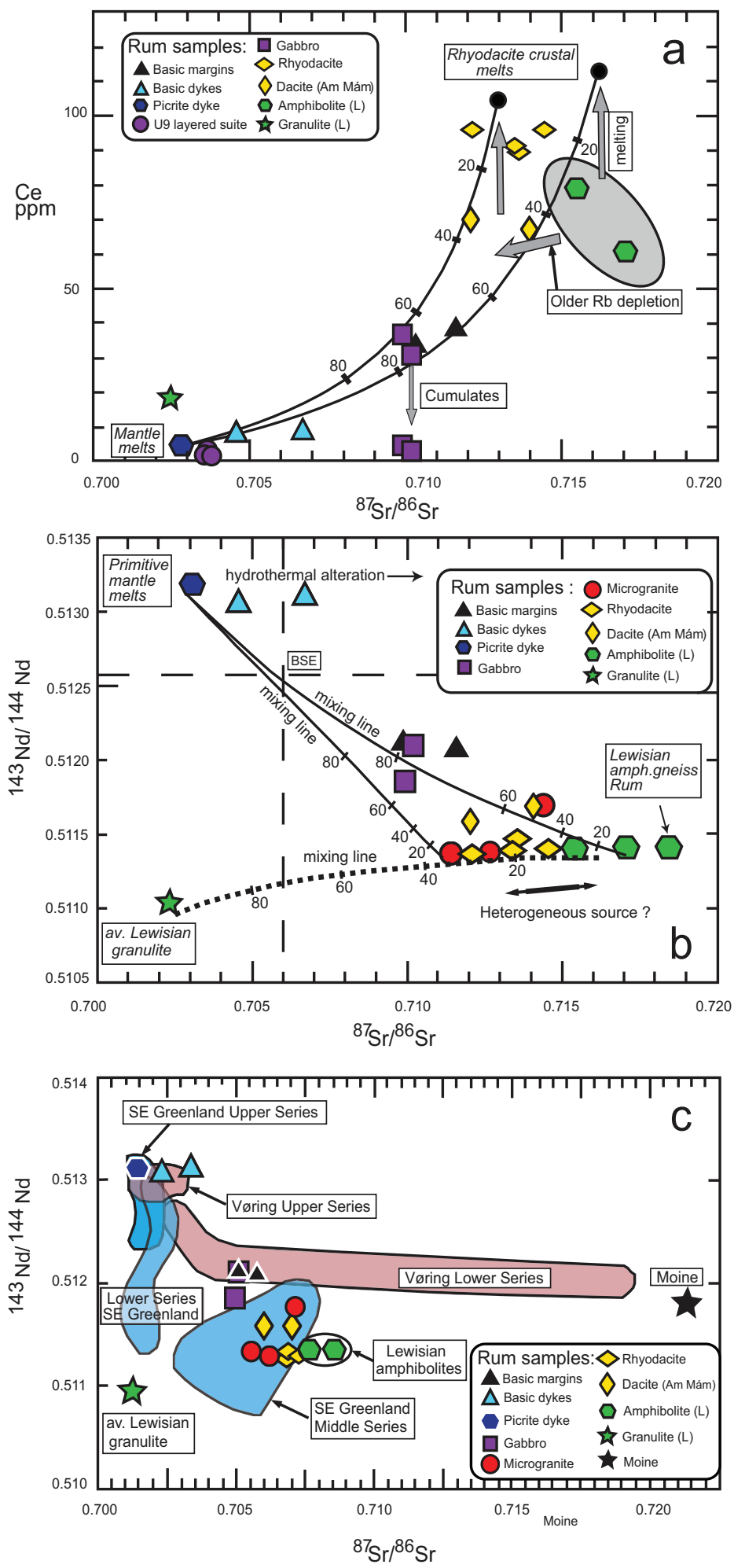

816 
crysts in the Kinloch Glen plug define a well developed flat-lying fabric and it is probable that the Kinloch Glen plug and by inference many others on Rum, also acted initially as volcanic conduits and feeder pipes to deliver magma to the surface.

\section{Magmatic replenishments, residual magma and fluid migration in the evolution of the ultrabasic rocks.}

The Rum Layered Suite is one of a handful of classic layered ultrabasic/ultramafic intrusions in terms of historical background, quality of exposure and advances made in scientific thinking. The Rum layered ultrabasic rocks have many structures and textures that mimic those found in clastic sedimentary rocks, including layering, graded bedding, slumping and soft sediment deformation, flame structures and rare channels (Figs 13, 14). These features suggest that early-formed crystals and crystal aggregates settled in less dense magma at rates which depended on densities and sizes; their accumulation and distribution sometimes being aided by magmatic currents, contributing to, for example, the strong lamination (Fig. 15a) and less common lineation found in many troctolites (e.g. Brothers, 1964). There is also the possibility that the calcic plagioclase $\left(\sim \mathrm{An}_{87}\right)$ may have floated in the picritic magmas, accounting for the small anorthosite blocks $(\sim 10-20 \mathrm{~cm}$ long) found commonly in the ELS, which, irrespective of final direction of movement (up or down), is a strong reminder of a highly dynamic, possibly convective magma system at that point in the Rum volcano's history. The range of acting processes produced texturally distinctive cumulus rocks where the cumulus crystals are frequently cemented by minerals precipitated from residual magma that was present in between the cumulus grains (Fig. 15b,c) (e.g. Wager et al., 1960; Wager and Brown, 1968).

Investigations made during the 1970s and 1980s led several researchers to conclude that magmatic sedimentation was inadequate to explain certain textural and structural features of the Rum layered rocks. This evidence ranged from the near-microscopic (Butcher, 1985) to the outcrop scale (Bédard et al., 1988). For example, at some localities there is evidence of small-scale metasomatism (Butcher, 1985), while elsewhere pervasive replacement of troctolite by peridotite has taken place (Fig. 16a,b) and an intrusive origin for many of the peridotite layers was postulated by Bédard et al. (1988), although verified subsequently for only the Unit 9 peridotites (e.g. Holness, 2005). Since the early 1990s it has become well established that igneous cumulates can form by a number of processes, of which traditional gravitational crystal settling is but one (e.g. Wadsworth, 1985) and that a continuing evolution of cumulates after solidification frequently overprints and obscures primary structural and textural features (e.g. Holness, 2007; Holness et al., 2005; 2007), thus often leaving an incomplete textural record.

It has been recognized that the Rum cumulates have relatively equilibrated textures (e.g. Faithfull, 1985) when compared with many dolerites or basalts. From measurements of dihedral angles using a universal stage mounted on an optical microscope, Holness and her co-workers (e.g. Holness, 2005, 2012a), have done much to quantify and assess the significance of the degrees of equilibration exhibited by igneous rocks on Rum and the effects of the processes involved. Through this work and building on earlier investigations, it is demonstrated that the layered rocks in eastern Rum have attained variable degrees of textural equilibrium, although none of them records the process as having gone to

Fig. 10 (facing page). (a) $\mathrm{Sr}^{87} / \mathrm{Sr}^{86}$ vs. Ce (ppm) for representative Rum samples (after Meyer et al. 2009). Ce is an incompatible element and is highly enriched in crustal rocks. The increasing Ce concentrations with increasing $\mathrm{Sr}$ isotope ratios is indicative of strong crustal influences on the felsic members of the Rum igneous suite. (b) $\mathrm{Sr}^{87} / \mathrm{Sr}^{86}$ vs. $\mathrm{Nd}^{143} / \mathrm{Nd}^{144}$ isotope ratios for representative Rum samples. Picrite (M.9) is isotopically the most primitive sample while dykes and gabbros are displaced towards crustal compositions (Lewisian amphibolite- and Lewisian granulite-facies rocks). The acidic igneous rocks from Rum (rhyodacites, dacites, microgranites) spread along a mixing line between Lewisian amphibolite and granulite implying that either both types of crust were involved or that the main contaminant (the Lewisian amphibolites) had experienced some loss of melt during a previous heating event. (c) Comparison of the Rum Nd and Sr isotope ratios with data from other North Atlantic Volcanic Rifted Margins ODP Leg 152, SE Greenland margin and ODP Leg 104, Vøring Plateau. Note the similarities of the Rum suite with available SE-Greenland data (Fig. 10 modified after Meyer et al., 2009). 

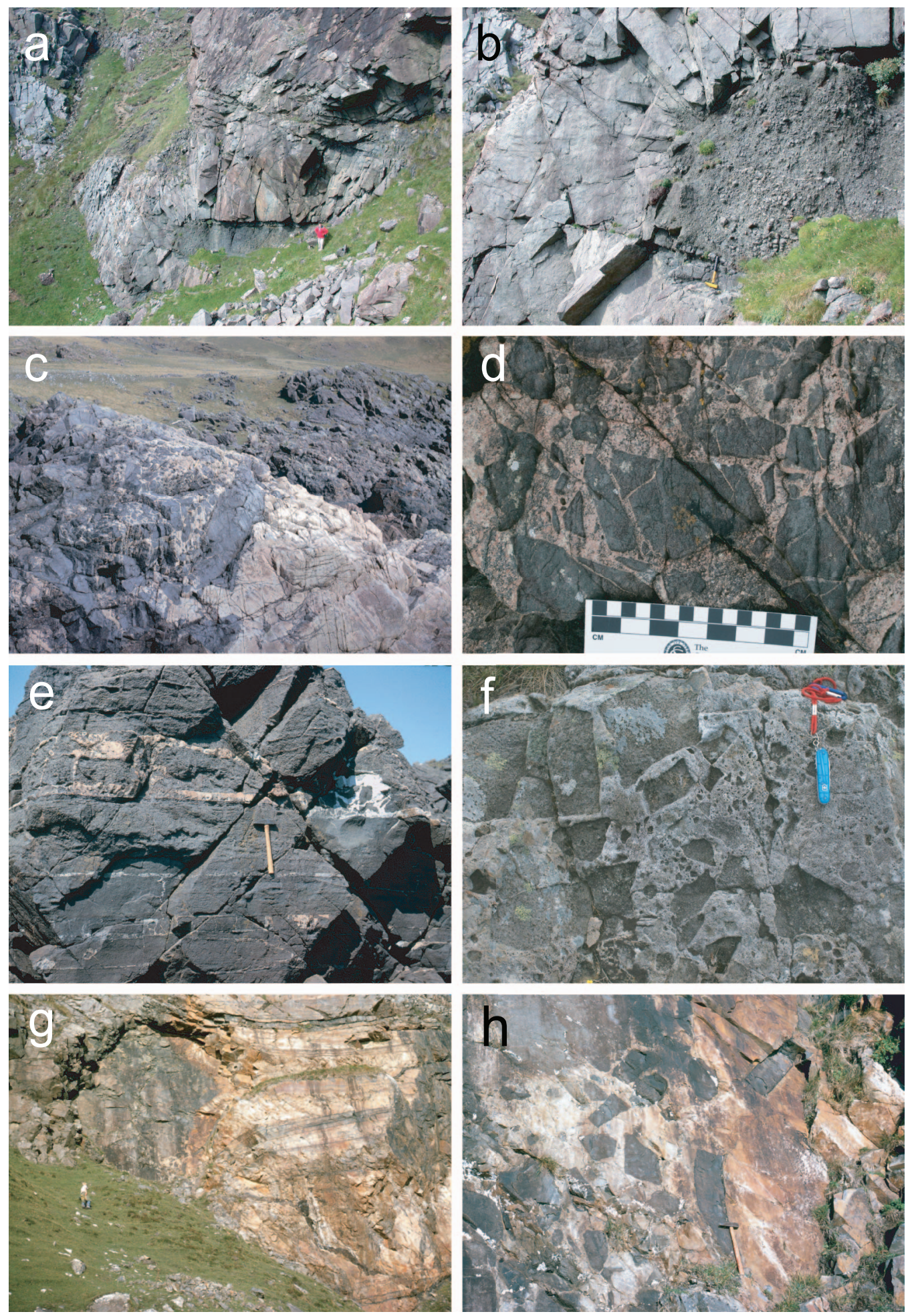
completion. In unmodified rocks, median angles of $\sim 80-90^{\circ}$ are common in troctolites, while they tend to be somewhat greater in the gabbros $\left(\sim 90^{\circ}+\right)$. There are numerous departures from these values and these have been attributed to heating or to metasomatism (e.g. Holness et al., 2012b). In Unit 10 (Brown, 1956), the degree of textural equilibration in troctolite was found to vary along the length of the unit and in one traverse (Holness et al., 2012a, traverse 'A'), fairly uniform dihedral angles $\left(\sim 90^{\circ}\right)$ were obtained until close to the top of the unit when the troctolites were noticeably more equilibrated. In another traverse, nearly $1 \mathrm{~km}$ distant, there was a relatively low degree of textural equilibration through most of the troctolite thickness until, again, textures record higher degrees of equilibration in the uppermost metres of the unit. From their measurement of the dihedral angles and with additional support from textural and compositional properties of augite, Holness et al. (2012a) concluded that much of the troctolite in traverse B had undergone significant 'infiltration metasomatism' by late-stage fluids from underlying peridotite, but that this had been absent from traverse A. In traverse A, the more equilibrated microstructures had formed during initial solidification, i.e. as the result of igneous processes. In both traverses, the increased equilibration evident in the top few metres was attributed to metamorphism by peridotite at the base of Unit 11 and thus, three controlling influences are recognized in the development of these microtextures, comprising igneous, metasomatic and metamorphic processes (Holness, 2007; Holness et al., 2005, 2007, 2012a).

Brown (1956), in his original investigation of the ELS, regarded the peridotites as integral, basal
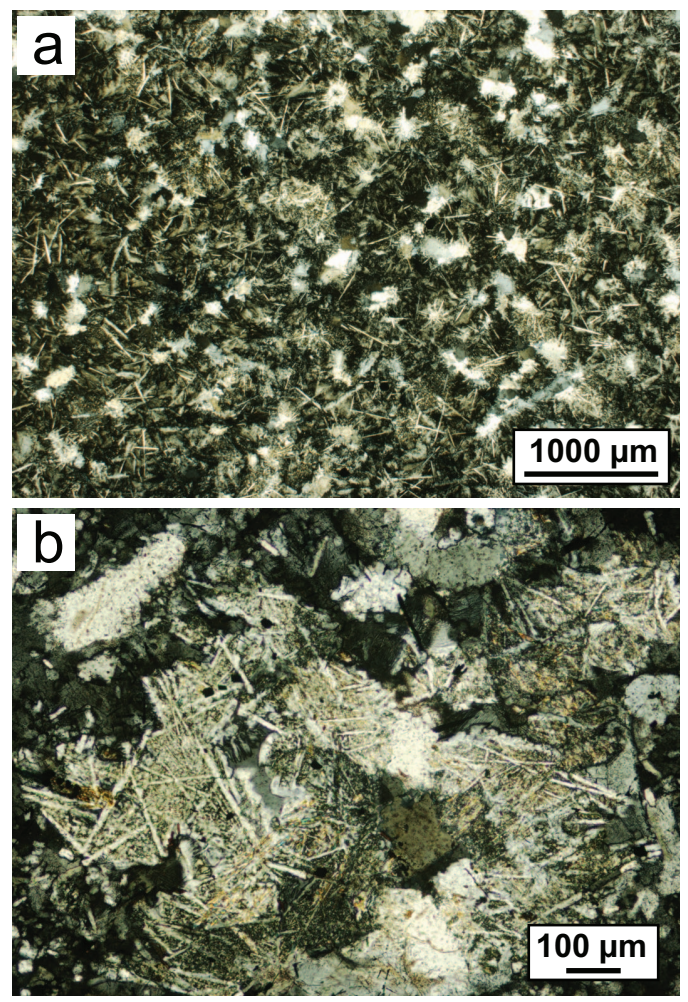

FIG. 12. Photomicrographs (crossed polarizers). (a) Quartz paramorphs after tridymite fringing relict quartz grains in partially fused Torridonian feldspathic sandstone adjoining the gabbro plug, north side of Kinloch Glen. (b) Spherulitic feldspar and tridymite paramorphs in a matrix of partially fused Torridonian feldspathic sandstone. The radial spherulitic texture developed particularly in partly melted sandstone next to a gabbro plug, Allt Bealach Mhic Neill, south side of Kinloch Glen.

FIG. 11 (facing page). Marginal relationships of the Ultrabasic Intrusion, Layered Suite: $(a, b)$ Tongues of harrisitic gabbro in bytownite gabbro (Western Layered Intrusion (WLI)) extending into a heated and ductile granite zone to the left, west of mausoleum, Harris Bay. Hammer for scale is $\sim 30 \mathrm{~cm}$. $(c, d)$ Zone of intrusion breccia at the contact of the Western Granite with later bytownite gabbro of the WLI, East end of Harris Bay. The line of dark blocks is a broken up dyke in the felsic granite matrix formed when granite was partially melted and mobilized by heating from the WLI gabbro. (e) Layered gabbro in the WLI intruded by remobilized ('rheomorphic') acidic veins derived from partial melting of the adjoining Western Granite. The acidic magma has been channelled along planes of weakness provided by the layered structures. East side of Harris Bay, hammer shaft $\sim 30 \mathrm{~cm}$. $(f)$ Back-veining breccia on Cnapan Breaca where marginal gabbro remobilized earlier acidic rhyodacite ignimbrites. The rheomorphic magma is being sucked into the cooling and hence increasingly jointed gabbro rock, leading locally to severe disintegration of the intruded gabbros. ( $g$ ) Gabbro of the Central Intrusion (dark rock above person) intruding bedded sandstone of the Sgorr Mhor Sandstone Member (right of photograph). Dark beds in the sandstone are relatively rich in heavy minerals. Note how the beds sag towards the steep contact, southeast of Loch Papadil. $(h)$ Detail of the intrusion breccia zone at the gabbro - sandstone contact of $(g)$. The light-coloured acidic matrix has come from the partial melting of the adjacent sandstone. Scale: hammer shaft $\sim 30 \mathrm{~cm}$. 
C. H. EMELEUS AND V. R. TROLL
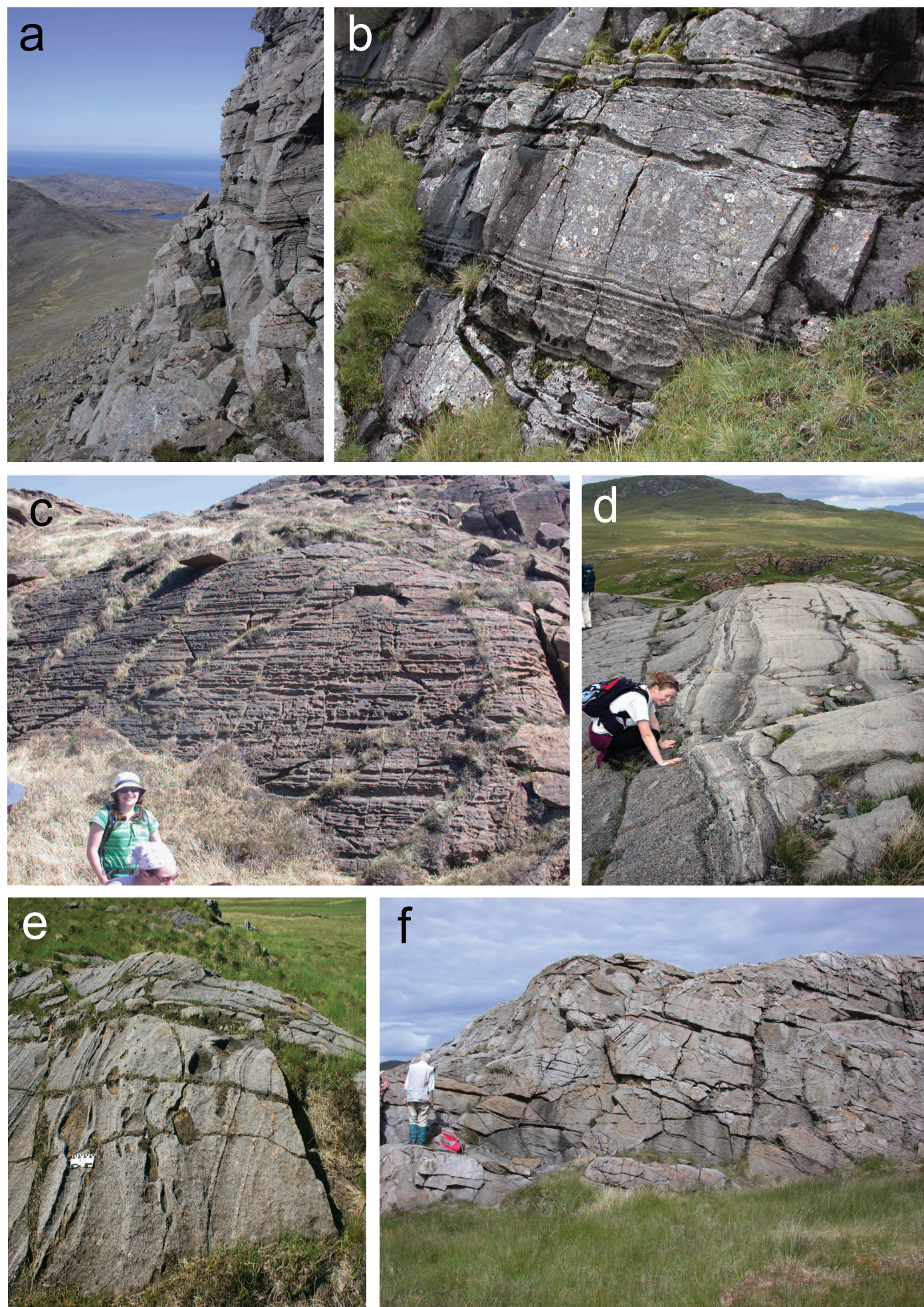
parts of each unit. This interpretation was challenged by Bédard et al. (1988) who demonstrated convincingly that the peridotite of Unit 9 was sheet-like (i.e. intrusive). Measurements of dihedral angles in a traverse across Units 8 and 9 revealed considerable variability in the degree of textural equilibration in troctolites, especially in the vicinity of the peridotite previously considered to form the base of Unit 9 (Holness et al., 2007). The variability was attributed to the intrusion of a sheet-like peridotite between the troctolites of Units 8 and 9, which perturbed the original igneous textures. Textural criteria may therefore be used to aid distinction between peridotites; those bordered by troctolite with apparently perturbed disequilibrium textures are probably intrusive, whereas uniformly equilibrated textures indicate peridotite that is an intergral part of a layered unit. Consequently, Holness et al. (2007) measured the dihedral angles in traverses across peridotite and troctolite in several of the units in the upper part of the ELS. The results showed that the Unit 9 peridotite was the only proven intrusive sheet, in contrast to the projection by Bédard et al. (1988) that the majority of peridotite may be later sheet-like intrusions (see Holness, 2005, 2007; Holness and Winpenny, 2009; Holness et al., 2012a).

Unit 9 contains a conspicuous pyroxene-rich gabbroic layer with an undulating, 'wavy' base that overlies troctolite at some distance above the intrusive peridotite (Figs 17a, 18a). This distinctive feature, historically termed the Wavy Horizon, contains pyroxene-rich structures which bear a striking resemblance to load casts and flame structures present in clastic sedimentary rocks that have undergone soft-sediment deformation (e.g. Collinson and Thompson, 1982). The Wavy Horizon and similar structures elsewhere have therefore been attributed to loading (Young and Donaldson, 1985; Volker and Upton, 1990, 1991) whereas Bédard et al. (1988) described features that strongly indicated a replacement origin for these structures. Holness et al. (2007) proposed that the pyroxene-rich rocks resulted from metasomatic infiltration processes that occurred when picritic magma, from the intrusive peridotite sheet, invaded partly crystallized gabbro. Residual fluids separating from the crystallizing peridotite ascended through the crystal mush, stripping out clinopyroxene until saturation was achieved. At that point, extensive pyroxene crystallization occurred and the Wavy Horizon developed (Figs 17a, 18). The relatively low dihedral angles in troctolite underlying the Wavy Horizon were attributed to rapid crystallization and the presence of small pockets of metasomatic liquid whereas the relatively high angles above this horizon (i.e. $>\sim 90^{\circ}$ ) may have been caused by the release of latent heat on crystallization of the abundant augite (Fig. 17b). Thus, the controversial Wavy Horizon has most recently been interpreted as a reaction front. Other examples from Rum are cited (Holness, 2007; Holness et al., 2005, 2007), underlining the potentially important role of migrating residual fluids in modifying and overprinting textures and compositions in the Rum cumulate pile.

Holness and Winpenny (2009) carried out a textural and geochemical examination of Unit 12, a well exposed layer in the upper part of the ELI. The upper troctolite varies in thickness from $17.5 \mathrm{~m}$ in the east to $13.5 \mathrm{~m}$ in the west and contains up to five thin peridotite layers which, with one exception (at $3.5 \mathrm{~m}$ ) are usually $\leqslant 50 \mathrm{~cm}$ thick. It was shown that the troctolite accumulated from up to seven separate batches of picritic to basaltic magma that intruded into a sill-like chamber which may have been as little as several tens of metres thick during much of its active growth (Holness and Winpenny, 2009).

The presence of spectacular slump structures in a number of units in the ELS but also in the CI, involving both troctolite and peridotite, together with peridotite layers overlain unconformably by further thin peridotite layers at a number of localities, shows that episodes of marked instability affected partly-consolidated cumulate mushes (Figs 13b, 19). The AMS data obtained from three of the units $(8,9$ and 10) of the ELS by

Fig. 13 (facing page). Classic cumulate textures in ultrabasic rocks of the Layered Suite. (a) Modally layered troctolite in $\sim 5 \mathrm{~m}$ high section on the southwest face of Hallival. The layering is defined by alternating feldspar- and olivine-rich portions, ELI. (b) Modally layered troctolite with small-scale slump structures (centre of image) and peridotite replacing troctolite (near base of $2 \mathrm{~m}$ high section), SE Hallival, ELI. (c) Fine-scale layering in troctolite. WLI, near Loch an Dornabac. (d) Layered troctolite overlying peridotite 'cobble avalanche' deposit. Central Intrusion. (e) Deformed, steeply dipping layered troctolite containing peridotite blocks, Central Intrusion. ( $f$ ) Coarse breccia of layered troctolite blocks in a peridotite matrix, Central Intrusion. 

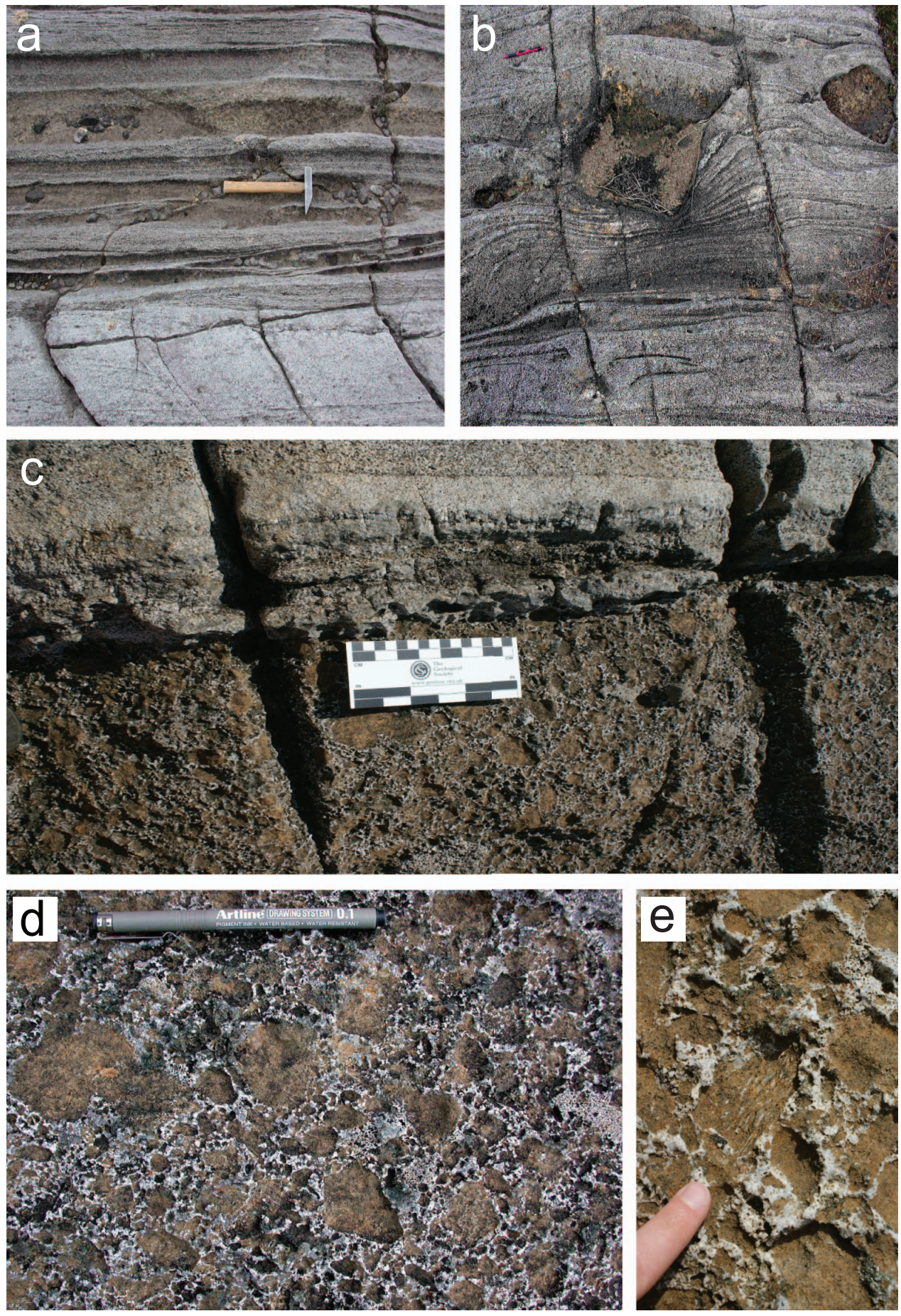

FIG. 14. Details of layering in the Central Intrusion. (a) Intricate, fine-scale layering in peridotite. Scale: hammer shaft $\sim 30 \mathrm{~cm}$. (b) Peridotite block ('dropstone') in troctolite. The underlying layering has been strongly deformed. Scale: central block is $\sim 20 \mathrm{~cm}$ across. $(c, d, e)$ Details of peridotite 'cobble avalanche', as in 13(d). Scale: pen $\sim 15 \mathrm{~cm}$. 

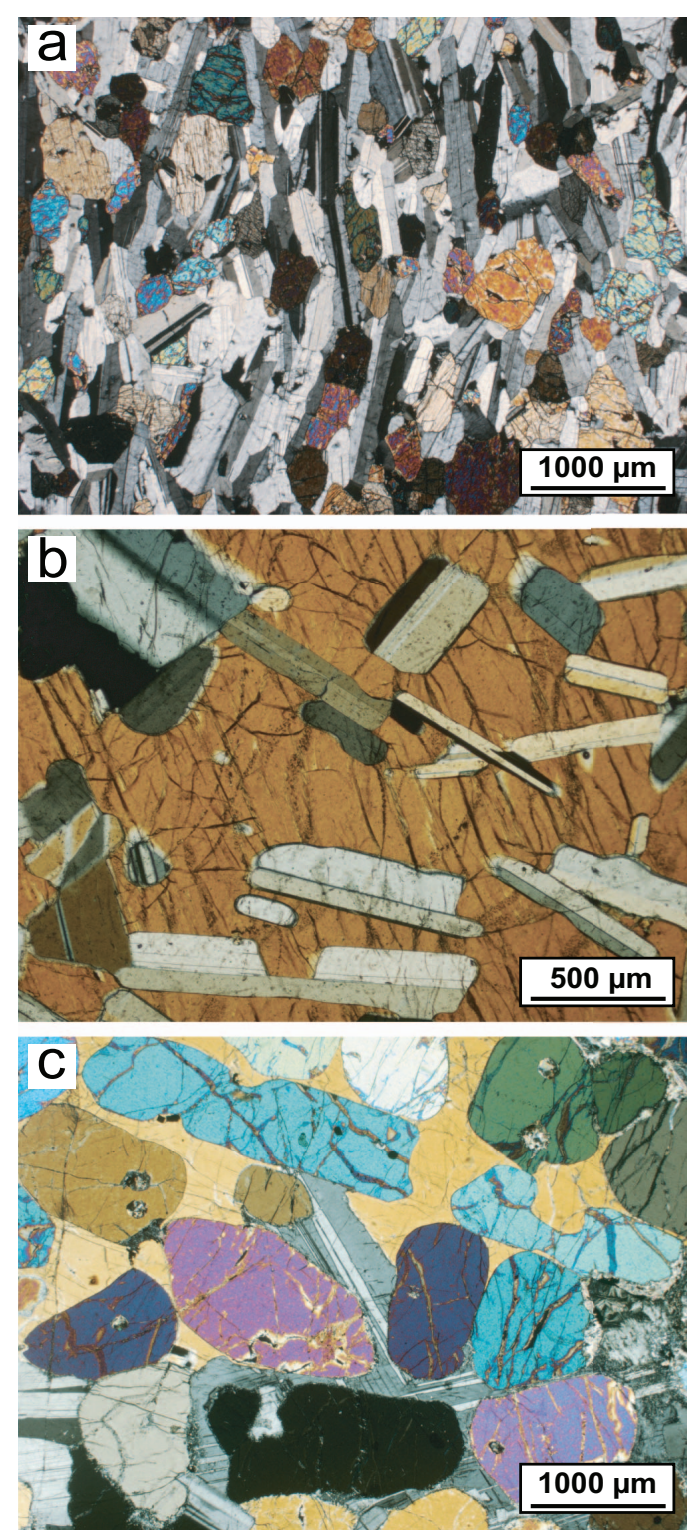

Fig. 15. Photomicrographs of 'classic' cumulate(s) from the ELI (all crossed polarizers). (a) Strongly laminated troctolite (allivalite) with cumulus plagioclase $>$ olivine $>$ clinopyroxene. Unit 10, north of Hallival. (b) Troctolitic cumulate with cumulus calcic plagioclase enclosed poikilitically by clinopyroxene. Unit 11, northwest face of Hallival. (c) Feldspathic peridotite. Typical olivine cumulate with olivine enclosed poikilitically in plagioclase. Unit 8, northeast of Hallival.
O'Driscoll et al. (2007b) showed the presence of a dominant magnetic foliation parallel to the magmatic layering defined by phase layering and feldspar (and olivine) lamination. In Unit 10, however, a detailed traverse revealed a southwest-trending magnetic lineation within but across the plane of the magmatic layering. The authors suggest that this magnetic fabric was imprinted during downslope slumping and sliding in the top few metres of crystal mush in response to central subsidence. Erosion prior to, during arrival of the next magma batch, or as this was emplaced, appears to have been commonplace. From this study, together with evidence from e.g. Unit 14 (Renner and Palacz, 1987) and Harris Bay (O'Driscoll et al., 2007a), it is evident that the Rum Layered Suite was constructed from a multitude of small batches of variably crustally contaminated magma pulses injected periodically into a continuously growing, but relatively thin sheet of resident magma. In this model, the macro-units would not be the result of fractionation of 16 large batches of magma, but would owe more to chance. The authors' interpretation is very much in accord with such an incrementally evolving sill-like body (e.g. Emeleus et al., 1996; Emeleus and Troll, 2008), rather than the major magma chamber model of earlier workers. A succession of thin sheets would bring together magmas that experienced variable degrees of magmatic evolution in deeper (mantle or crustal) reservoirs and therefore differs markedly from ideas that envisaged magma filling a single and large near-surface chamber (e.g. Huppert and Sparks, 1985). Furthermore, the contact metamorphic effects produced by the emplacement of a succession of sheets would be significantly less pronounced, as is apparently reflected in the limited zone of melting in the adjacent country rocks. By considering the way active volcanic systems in e.g. Iceland behave, the notion of many small replenishments in the Rum Layered Suite appears entirely reasonable.

The Katla volcano, for example, is characterized by a $\sim 30 \mathrm{~km}$ diameter volcanic edifice on which a $\sim 14 \mathrm{~km}$ diameter caldera is located that produced major rhyolitic eruptions in its past, like the $\sim 12,000$ years BP Sólheimar ignimbrite $\left(6-7 \mathrm{~km}^{3}\right.$; Lacasse et al., 1995, 2007). Volcanism from Katla over the last 8400 years, has been dominantly basaltic with frequent deposition of mafic tephra (Larsen, 2000; Óladóttir et al., 2005). Over this period, Katla produced $>300$ basaltic tephra eruptions 


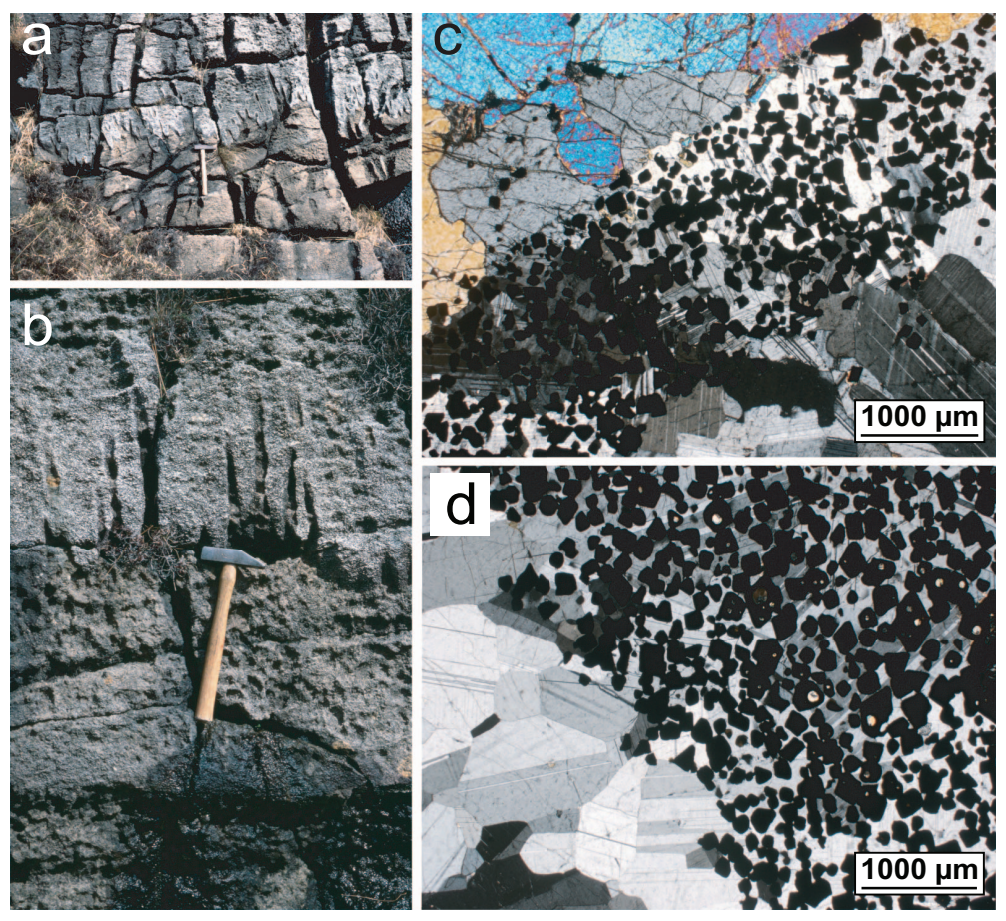

FIG. 16. (a) Peridotite fingers penetrating undisturbed, overlying layered troctolite. Central Intrusion, east of Minishal. Scale: hammer shaft $\sim 30 \mathrm{~cm}$. (b) Detail of finger structures from Fig. $16 a$ recording corrosion/replacement of layered troctolite by peridotite. Note how the brown peridotite at the base of the section cuts across the layering and sends irregular finger-like projections into the overlying troctolite. $(c, d)$ Photomicrographs of a chromitite seam at the boundary of Units 11 and 12, northwest of Hallival, (crossed polarizers). Note the sharp boundary of the chromitite seam with the adjoining chromite-poor peridotite (above) compared with the more gradational boundary against anorthositic troctolite (see below the seam). Numerous small, rounded inclusions in chrome-spinel crystals may contain biotite and/or amphibole.

(Óladóttir et al., 2005), probably reflecting many individual pulses of replenishment from depth. About 20 eruptions are documented for the last 1100 years alone; virtually all are of basaltic to sometimes intermediate compositions, but with limited discharge volumes. Prehistoric basaltic eruptions were even more frequent with estimates of up to six per century (Óladóttir et al., 2008). The manner in which magmatic intrusions evolve and supply eruptions has exercised geologists for quite some time and the importance of Rum lies in the abundant evidence it provides of growth by accretion through small but successive batches of basic magma, potentially similar to what might be happening under Katla today.

Distinctive coarsely crystalline ultrabasic rocks, originally termed 'harrisite' by Harker (1908), contain layers of branching elongate and dendritic olivine crystals many $\mathrm{cm}$ long
(Fig. 20a-e). From crystal-size distribution measurements (CSD) and estimated crystalgrowth rates, O'Driscoll et al. (2007a) suggested that olivine in the harrisitic peridotite crystallized rapidly (in hours or days) when incoming picritic magma achieved supersaturation in olivine due to significant undercooling, resulting in rapid crystal growth on the substrate (the chamber floor) beneath cooler resident magma. The process was repeated many times and incoming and/or resident magmas are sometimes recorded to have broken off and entrained the delicate tips of upward-growing harrisitic olivine (e.g. Fig. 20e, 21a,b). Intervening layers of mediumgrained peridotite resulted from episodes when undercooling was less pronounced (Fig. 20a). In contrast, the equally striking 'poikilo-macrospherulitic' structures formed by radiating poikilitic plagioclase crystals in the Central Intrusion 

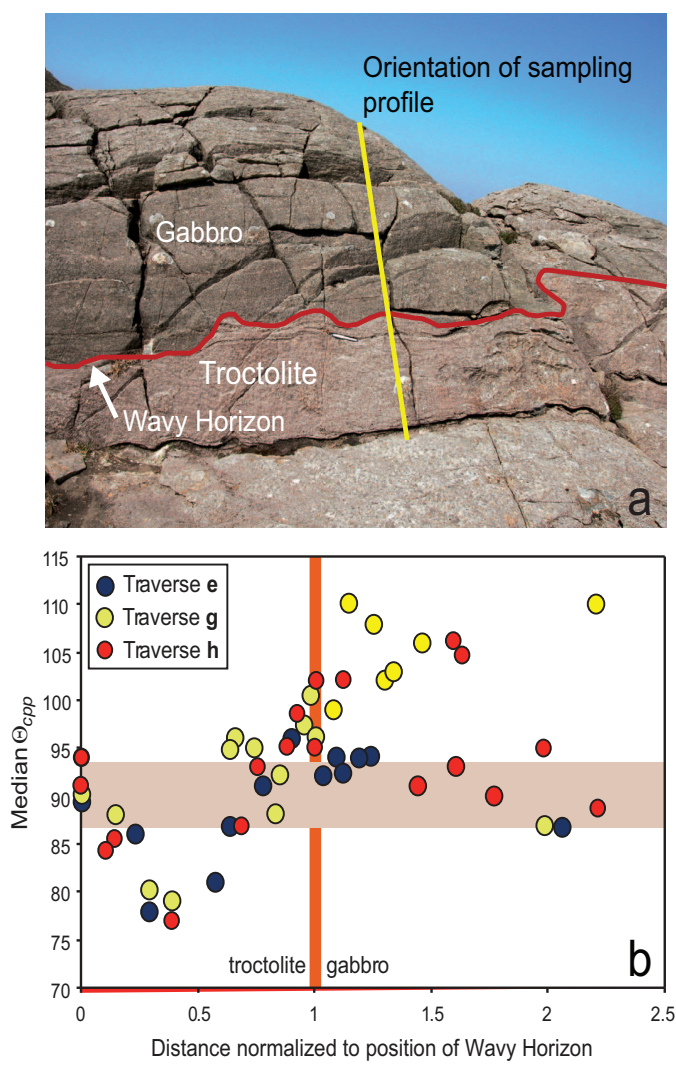

FIG. 17. (a) A $2 \mathrm{~m}$ high face north of Hallival shows the Unit 9 Wavy Horizon, separating layered troctolite from overlying dark, pyroxene-rich gabbro, ELI. The position of traverse $\mathrm{g}$ is indicated (modified after Holness, 2005). (b) Dihedral angles measured in three traverses through the Unit 9 troctolite and gabbro overlying the Unit 9 peridotite. The dihedral angles have been reset in troctolite adjoining the intrusive peridotite and at the troctolite/gabbro boundary, implying the underlying peridotite to be a later intrusive sill. The horizontal bar shows the comparatively small dihedral angle variation in Unit 10, Traverse ' $a$ ' (Holness, 2005, fig. 1; = Traverse ' $A$ ' in Holness et al., 2012)) where the basal peridotite is an integral part of the unit and not a later intrusion (based on traverses e,g,h, in Holness, 2005, fig. 1)

(Fig. 20f), grew in an olivine-rich crystal mush, probably from a hydrous feldspathic peridotite magma (Donaldson et al., 1973).

The intense but localized thermal metamorphism caused by the peridotite plugs that intruded Torridonian sandstones have already been considered (see above) and Holness et al. (2012) concluded that the plugs and peridotite tongues (see e.g. Dunham, 1965) were pipe-like feeders through which olivine-bearing basalt magma was erupted for as much as several months. The modal percentage of olivine in the pipes varies from 50 vol. $\%$ at the margins to over 85 vol.\% in the centres, where tabular crystals define a weak horizontally oriented planar mineral alignment. From an examination of their CSD it is suggested that the olivine grains were clustered, the fabric and high modal percentage of olivine in the plug centres arising through a combination of settling of the crystal clusters after cessation of magma flow followed by overgrowth from interstitial liquids. This, together with mechanical rearrangement, further strengthened the fabric and the effects were most pronounced in the slowercooled pipe centres where there is little evidence of compaction. A similar mechanism is suggested for the WLI where quantitative textural analysis of peridotite indicates that there has been no significant post cumulus recrystallization and no significant compaction by pressure solution (Worrall et al., 2003). This conclusion is radically different from that of Sparks et al. (1985) who considered compaction to be of major importance in the formation of adcumulates, especially in thick cumulates (e.g. $>100 \mathrm{~m})$. The degree to which pore fluids are retained could have a significant bearing on the mechanical stability of cumulates and from investigations on e.g. the Muskox Intrusion (Irvine, 1980) and the Lilloise Intrusion (Brown et al., 1986) it was suggested that thicknesses of the order of $300 \mathrm{~m}$ of unconsolidated cumulates had existed in these intrusions. Did the Rum cumulates retain significant pore liquid and remain unconsolidated to these depths? Well documented slump structures and deformed layering are ubiquitous, especially in the troctolites (e.g. Brown, 1956) and certainly must have involved substantial cumulate thicknesses (Emeleus, 1997; Emeleus and Troll, 2008, fig. 29). Furthermore, major instability, involving mass flow of cumulates towards the centre of the intrusion, was claimed by Elias (1989) and O'Driscoll et al. (2007b). Instability possibly facilitated by trapped pore fluids is further indicated by the manner in which both the ELI and WLI cumulates border the Central Intrusion, as both units appear to become deformed and increasingly disintegrated towards the Central Intrusion (Wadsworth 1961; Volker and Upton, 1990), probably accounting for the rafts and mega-blocks of layered cumulate that are so frequent within the Central Intrusion. 
C. H. EMELEUS AND V. R. TROLL
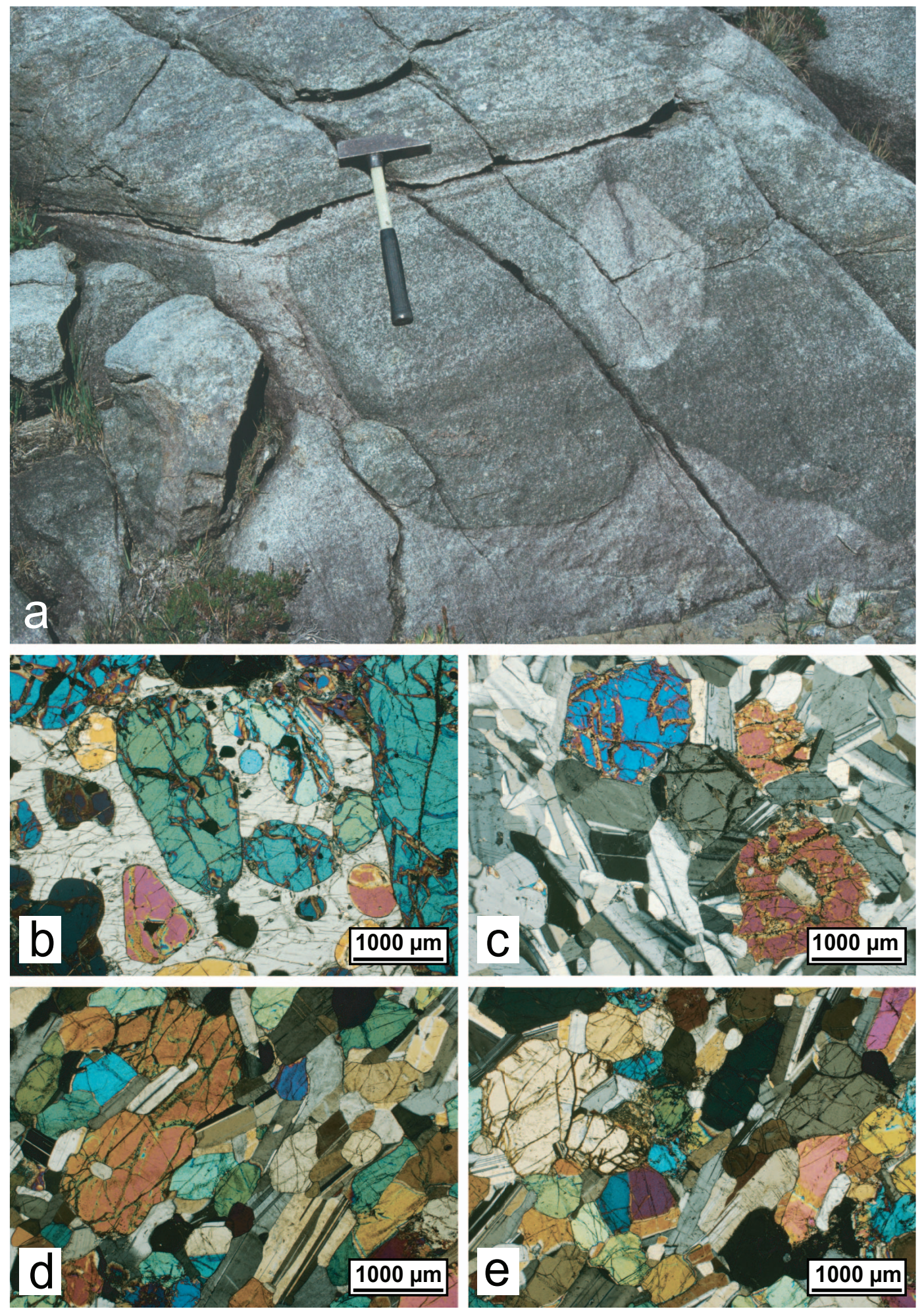
The origin or origins of the Rum basic magmas have been the subject of numerous investigations and were summarized by Emeleus (1997); the current consensus is that these were of olivinerich basaltic or picritic compositions. Several small dykes with unusually Mg-rich compositions were investigated geochemically and isotopically by Upton et al. (2002) and one dyke in particular ('M.9') exhibits exceptionally primitive characteristics (Fig. 22). This dyke includes forsteritic olivine $\left(\mathrm{Fo}_{93}\right)$, aluminous spinel and mantle-like $\mathrm{Sr}-\mathrm{Nd}$ isotopic ratios. The magmas responsible for these dykes are considered to have been Mg-rich ( $\mathrm{MgO}$ 18-20 wt.\%) high-temperature picrites derived mainly from a depleted garnet-lherzolite mantle source (Upton et al., 2002). It is suggested that the Icelandic plume mantle may have been involved, with local melting possibly aided by activity on the Long Loch Fault (Upton et al., 2002; O'Driscoll et al., 2009a). Notably, however, the 'M.9' picrite shows a slight offset in $\mathrm{Pb}$-isotope space relative to the mantle field, suggesting, nevertheless, that a small amount of crustal assimilation occurred during its journey from the mantle to the surface (Nicoll, 2007). Combined with the observation of a very high olivine crystal content, the bulk of $\mathrm{Mg}$ is probably not fully representative of a parental magma, yet, it provides us with some constraints on what primitive magmas feeding Rum may have 'looked like' in a compositional sense. It will remain a challenge to define the Rum parental magma for some time, as even quenched and glassy materials from picrite dykes tend to be affected by exchange with their surroundings on emplacement (unpublished oxygen data of the authors frequently indicates high-temperature interactions with crustal fluids).

\section{Chrome-spinel and Pt-group elements in the ultrabasic rocks of Rum}

Chrome-spinel commonly occurs concentrated in thin $(1-5 \mathrm{~mm})$, laterally extensive seams at the boundaries between major layered units, the classic example being at the Unit 11/12 contact, but chrome-spinel is also disseminated through both peridotite and troctolite. Although the seams were originally attributed to settling of dense chrome-spinel crystals (e.g. Brown, 1956), in some instances with strong supporting evidence (e.g. Volker and Upton, 1990), they can also display a wider range of attentive structures. The small size of individual crystals (commonly $<0.5 \mathrm{~mm}$ in diameter), the, in places, nonstratiform and variable behaviour of seams (Figs $16 c, d, 23)$ and CSD measurements, cast doubt on the original cumulate interpretation (O'Driscoll et $a l ., 2009 a, b, 2010)$.

The 'main seams' (e.g. those at Unit $7 / 8$ and Unit 11/12 boundaries; see also Figs $16 c, d, 23)$ are commonly underlain by chrome-spinelbearing anorthositic troctolite that contains one or more faint, but laterally persistent, subsidiary seams a short distance below the seam. The subsidiary seams remain parallel across outcrops, but close to the bases of the seams the anorthosite gives way abruptly, along a broadly planar surface with minor irregularities, to disturbed troctolite containing contorted peridotite schlieren and anorthositic pods. At unit boundaries, the main seams may also form cone-like concentrations of chrome-spinel (up to $2 \mathrm{~cm}$ thick) that project downwards into anorthosite. Fragments of cone tips appear to be broken off and suspended in anorthosite (Fig. 23b) and well developed lamination in the anorthosite may persist across the cones. Thin irregular chrome-spinel rich veins and 'supra-seams' penetrate the peridotite overlying the main seams and where this occurs, the main seam is often absent or diminished in thickness. Cumulus olivine in the peridotite may be coated by chrome-spinel and olivine crystals on the seam surface may appear truncated (Fig. 23c). These relationships are explained by the ability of hot, downwards-percolating picritic liquid that partially melted considerable amounts of troctolite (e.g. O'Driscoll et al., 2009b), causing chrome-spinel and anorthite-rich feldspar to precipitate on cooling, exploiting nuclei provided

FIG. 18 (facing page). The Unit 9 Wavy Horizon, ELI. (a) Undulatory contact between troctolite and overlying dark, pyroxene-rich gabbro. The lamination and weak layering in the troctolite is approximately parallel to the layering and lamination in the overlying gabbro yet plumes/fingers of one have punctuated the other. Locality close to Fig. 13. Scale: hammer shaft $35 \mathrm{~cm}$. $(b-e)$ Photomicrographs of Unit 9 lithologies (all crossed polarizers). (b) Peridotite with large poikilitic clinopyroxene. (c) Allivalite (troctolite) with feldspar lamination. (d,e) Pyroxenerich gabbro immediately above troctolite at the Wavy Horizon. The clinopyroxene is strongly laminated. 

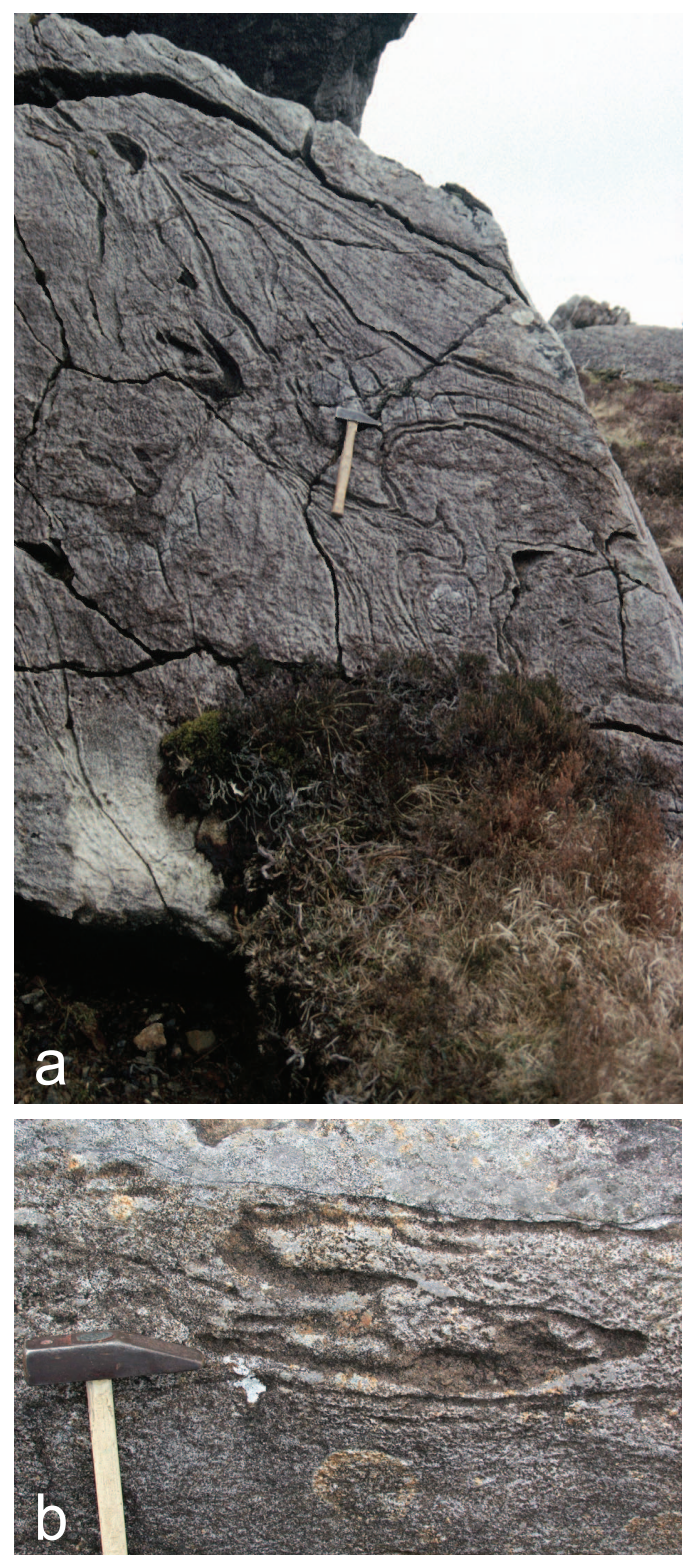

FIG. 19. (a) Extensive slumping in the Unit 13 troctolite, on the north side of Hallival, ELI. Scale: hammer shaft $\sim 30 \mathrm{~cm}$. (b) Deformed layering in the Unit 14 troctolite with structures that share similarities to slump structures in sedimentary rocks. South face of Askival.

by residual troctolite crystals. The subsidiary seams then define the lower level(s) of reconstitution of troctolite to form anorthosite. These supra seams and the associated localized chrome-spinel enrichment of peridotite, together with cone structures and other irregularities at unit boundaries are envisaged to have formed during synmagmatic deformation. These conclusions, which are reinforced by mineral compositional and textural evidence, are compatible with the chrome-spinel seams having undergone significant post-cumulus structural, textural and compositional modifications and Power et al. (2000a) make the case that the use of chrome-spinel as an indicator of provenance and petrogenesis is probably compromised by the wide range of processes now recorded.

Micron-sized sulfide and Pt-group minerals are also present in the ultrabasic rocks of Rum, commonly in association with chrome-spinel or chrome-spinel seams and laminae, but also at contacts between peridotite and sedimentary rocks as well as in heavy-mineral concentrations in streams and off-shore deposits derived from the Central Complex (Butcher et al., 1999; Power et al., 2000b, 2003). The Pt-group ('PG') minerals usually occur at grain boundaries (sulfide with silicate and chrome-spinel; sulfide-silicate) or, rarely, enclosed by chrome-spinel. A range of Pt$\mathrm{Fe}$ and $\mathrm{Pt}-\mathrm{Cu}$ alloys are described from the layered ultrabasic rocks, along with laurite, sperrylite, Pt-Pd-bearing bismuthides, tellurides and antimonides. Whole-rock PGE concentrations show a gentle positive trend on PGE chondrite normalized diagrams and their concentration is attributed by Power et al. $(2000 \mathrm{~b}, 2003)$ to anomalously large melt production associated with a proto-Icelandic hotspot early in North Atlantic rifting, coupled with magma mixing during periodic magma recharge that allowed preferential precipitation of sulfides and related mineral assemblages. The Rum PG minerals have been slightly affected by hydrothermal circulation (Power et al., 2000b). Specifically, in a review of the diverse Pt-group element mineralization styles in the Palaeogene North Atlantic Igneous Province, Power et al. (2003) give an account of the sulfide-hosted Pt and Pd minerals found in the margins of a peridotite plug in northwest Rum and in associated pyrrhotite-rich dykes ( $>40$ modal $\%$; Power et al., 2003). The Pt-group minerals are disseminated throughout the peridotite of the plug and, although generally uncommon in the pyrrhotite-rich dykes, Pt-minerals were found in high concentrations and relatively large sizes $(1-40 \mu \mathrm{m})$ in one thin chalcopyrite- and pentlandite-bearing dyke. There, paolovite $\left(\mathrm{Pd}_{2} \mathrm{Sn}\right)$ is the dominant Pt-group mineral. Total 

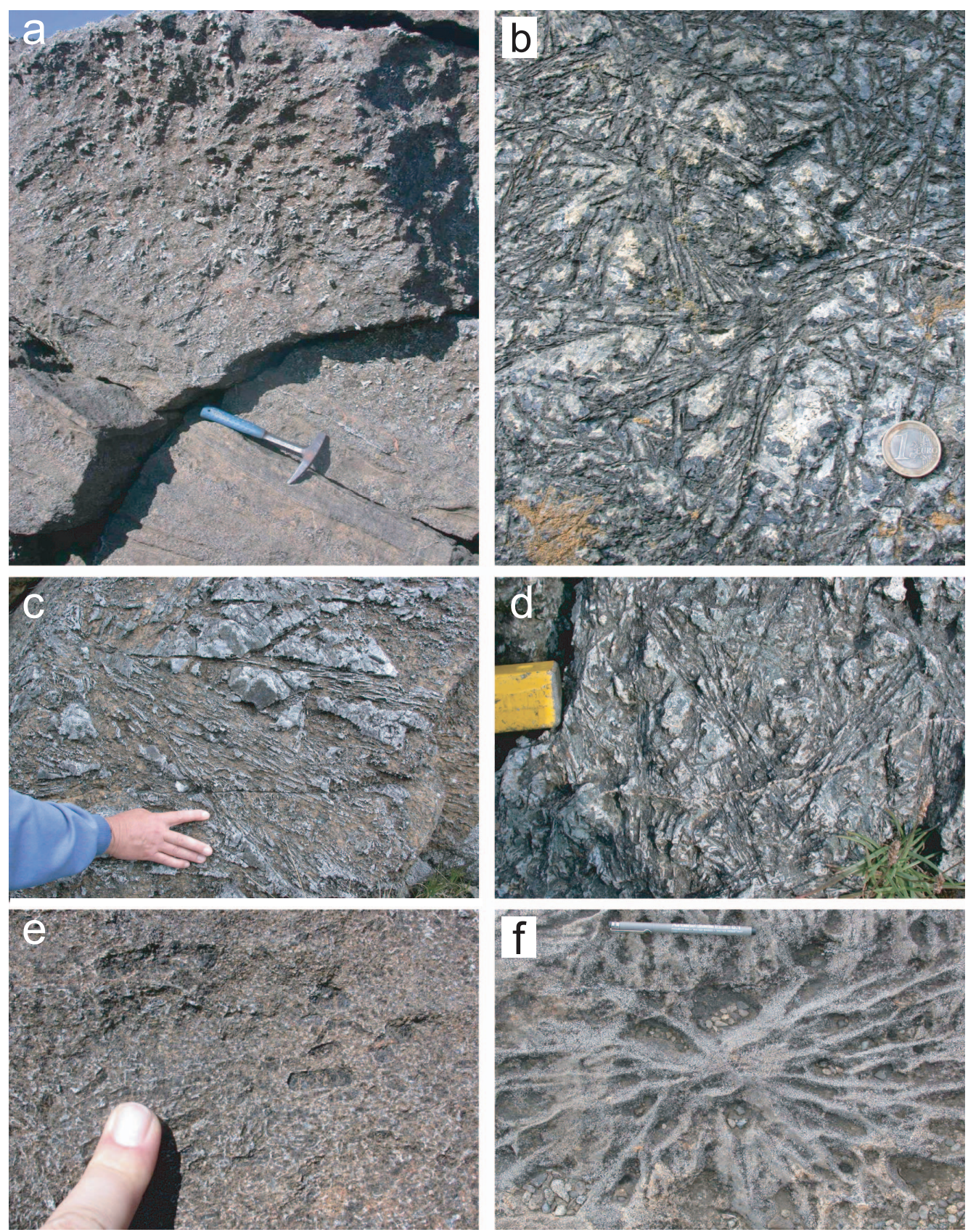

Fig. 20. (a) Harrisitic structures in peridotite and gabbro of the Western Layered Intrusion. Surface showing the weathering out of elongate olivine crystals in typical harrisite for comparison with the smooth surface of the underlying layered peridotite (below hammer). Episodic growth of harrisites is indicated. $(b, d)$ Meshwork of harrisitic olivine crystals. Harris Bay. (c) Elongate, skeletal olivine crystals ( $\sim 1 \mathrm{~m} \mathrm{long})$ WLI. (e) Fragments of olivine crystals in normal peridotite WLI. These have been broken off from the underlying harrisite layer (see Fig. 21a,b). $(f)$ Spherulitic growth of feldspar in troctolite ('poikilo-macrospherulitic' structures, Donaldson et al., 1973), Central Intrusion. Scale: pen $\sim 15 \mathrm{~cm}$. 

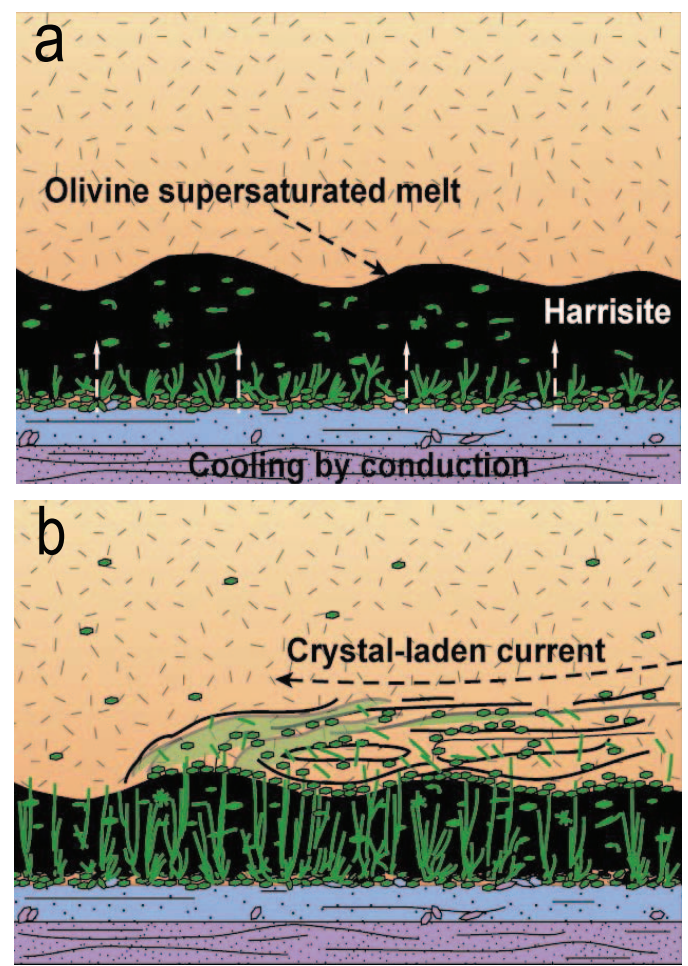

FIG. 21. $(a, b)$ Successive stages in the formation of harrisitic structures (after O'Driscoll et al., 2007). Harrisitic olivine growth $(a)$ is repeatedly interrupted by replenishments to produce both in situ and broken varieties $(b)$.

Pt-group element concentrations in the dyke can be $>2000 \mathrm{ppb}$, considerably greater than in the peridotites, with a significant proportion held in solid solution in sulfides. Sulfur isotopes indicate that this particular magma was contaminated with sulfur from local sedimentary sources, probably with Lower Jurassic shales or carbonate-impregnated Triassic sandstones (also known as 'cornstones'), while the high Pt-group elemental concentrations in the peridotite plug were possibly derived from sulfur-rich liquids that may have segregated from inside a larger magma body below the present-day exposure level (Power et al., 2003).

From an investigation of Re-Os isotopes and the Pt-group elements in three units of the ELI, O'Driscoll et al. (2009a) proposed that there is a range in initial ${ }^{187} \mathrm{Os} /{ }^{188} \mathrm{Os}$, which they interpret as inhomogeneity in the replenishing magmas (but see also Power et al., 2000a,b). They also
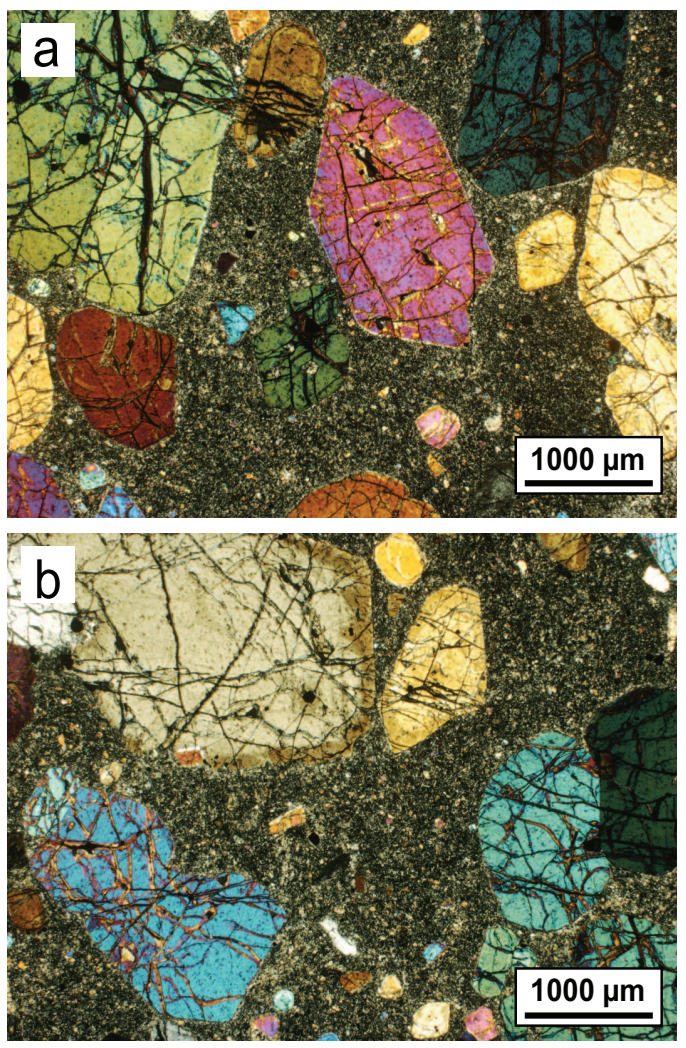

FIG. 22. $(a, b)$ Photomicrographs of picrite dyke 'M.9' (see Upton et al., 2002) that intruded peridotite in the WLI (crossed polarizers). Quarry at summit of Harris road, east of Ard Nev. Olivine can be clouded (large crystal at top-left in $(b))$ and often appears black in hand specimen, probably a high-temperature oxidation effect. In $(b)$ the groundmass contains colourful olivine together with fine-grained needle-like plagioclase and small clinopyroxene crystals. M.9 is one of the most primitive (basic) compositions known from Rum.

suggested that the processes responsible for formation of chrome-spinel seams led to the concentration of the Pt-group elements. The range of initial Os isotopes was modelled by assuming assimilation of up to $8 \%$ Lewisian gneiss, with changing Pt-group element contents in the replenishing magmas due to progressive sulfide removal. The modelled Os parental isotopes resemble those present in basalts and picrites elsewhere in the North Atlantic Igneous Province (e.g. recent Icelandic lavas). The close connection between sulfide minerals, Pt-group elements and chrome-spinel seams has been further investigated 

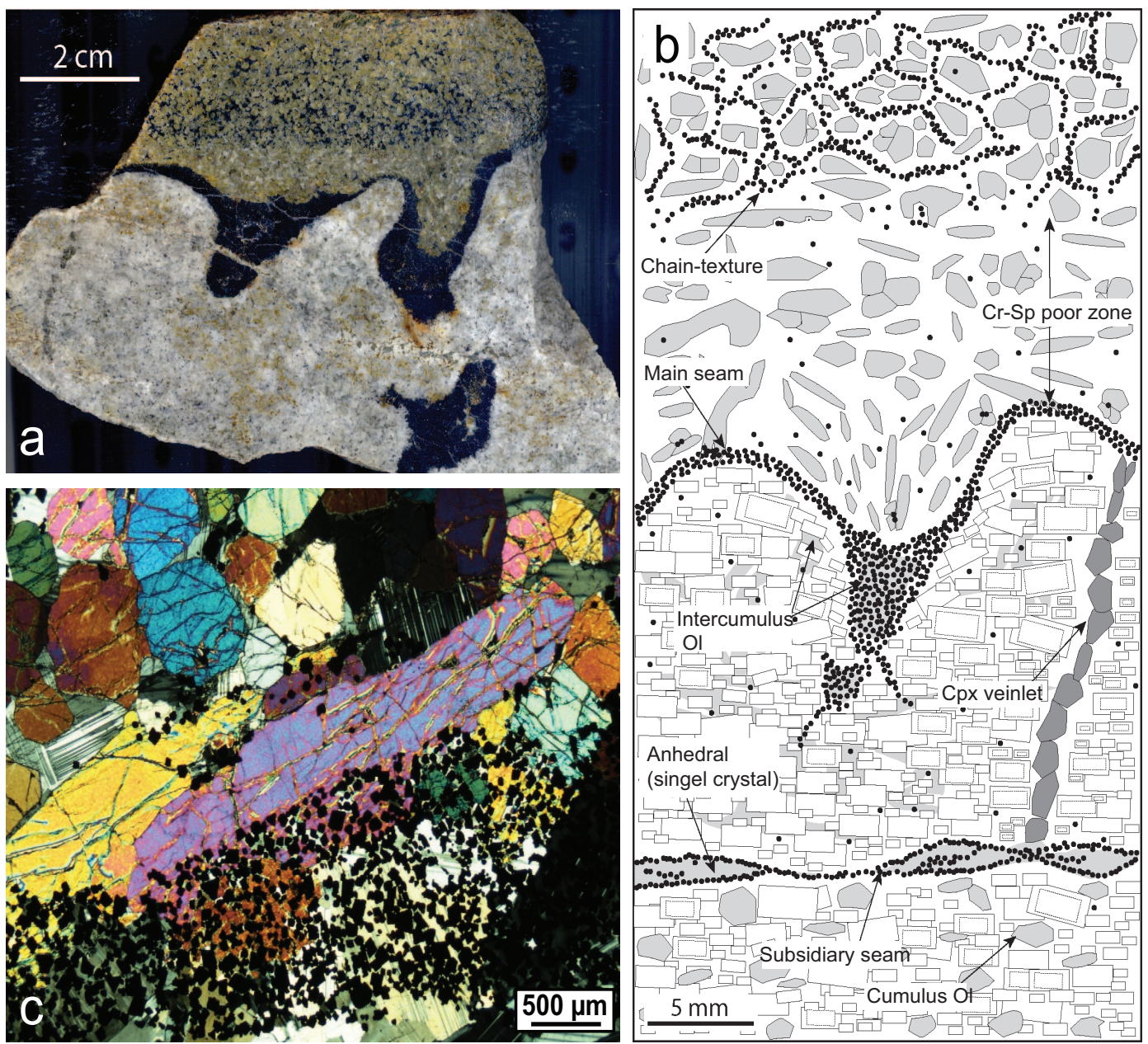

Fig. 23. (a) Polished surface of downward-projecting chrome-spinel-rich cones developed on a chromitite seam (the Main Seam) at the contact of Unit 8 peridotite with underlying Unit 7 anorthositic troctolite. The cone structures transgress the flat-lying feldspar lamination in the troctolite and a package of chromitite appears to be detached from the right-hand cone, or, represents an elongation outside the area of view. Head wall of Coire Dubh. (b) A sketch of the relationships at the Unit 7/8 boundary shown in $(a)$. A chrome-spinel-poor zone overlies the main seam and is in turn overlain by chrome-spinel-enriched peridotite. A subsidiary chromitite seam is underlain by laminated troctolite and separated from the overlying main seam by up to $20 \mathrm{~cm}$ of well laminated anorthositic troctolite that contains the detaching tip of a cone and is traversed by a near-vertical clinopyroxene veinlet. (c) Flat-lying, elongate cumulus olivine crystal apparently truncated at the Main Seam (crossed polarizers; crystal $4.5 \mathrm{~mm}$ long; after O'Driscoll et al., 2010).

by Latypov et al. (2013) who cite evidence for the in situ growth of the chrome-spinels at a liquidcrystal interface. The chrome-spinel, in turn, provided favourable sites for sulfide growth from droplets which had scavenged Pt-group elements from continuously convecting picritic magma.
The age and duration of the igneous activity at Rum

The Rum Centre has been shown to pre-date the Skye Centre ( $\sim 59 \mathrm{Ma})$ (Williamson and Bell, 1994; Hamilton et al., 1998). On Rum, alkaline segregations and pegmatites associated with mafic 
rocks of Stage 2 yielded ages of $60.53 \pm 0.08 \mathrm{Ma}$ $(\mathrm{U}-\mathrm{Pb})$ and $60.1 \pm 1.0$ (Ar-Ar) (Hamilton et al., 1998) and further work on the Western Granite gave an Ar-Ar age of $60.01 \pm 0.45 \mathrm{Ma}$ (Chambers et al., 2005). Additional constraints on the timing and duration of igneous activity were provided by Troll et al. (2008), who used laser ablation techniques on single crystals to determine the ${ }^{40} \mathrm{Ar} /{ }^{39} \mathrm{Ar}$ ages in a suite of plagioclases from the Stage 1 rhyodacites (Fig. 24). An age peak at $60.33 \pm 0.21 \mathrm{Ma}$ was equated with eruption of the rhyodacites. This new age constraint overlaps with that for the ultrabasic intrusion $(60.53 \mathrm{Ma})$, implying the latter was already forming at depth and supplying the necessary heat for crustal melting during the early acidic and acid/basic activity, which is in accord with the presence of gabbro and peridotite fragments in the Am Màm intrusion breccias of Stage 1. Quickly thereafter, the ultrabasic magmas migrated upwards to shallow structural levels and intruded into the volcano's earlier deposits. When combined with other age determinations on Rum and its surroundings, it seems the whole sequence of igneous and associated tectonic events at the Rum centre took place in maybe as little as $\sim 500 \mathrm{ka}$. Subsidiary peaks at $\sim 61.4$ and $63 \mathrm{Ma}$ on the feldspar age-distribution profile (Fig. 24b) were attributed by Troll et al. (2008) to recycled and largely re-equilibrated feldspars derived from crustal rocks whose assimilation and partial melting contributed substantially to the silicic rocks of Stage 1 (e.g. Geldmacher, 2002; Troll et al., 2004; Meyer et al., 2009). The end of igneous activity within the Rum Central Complex, in turn, is marked by the Canna Lava Formation

FIG. 24 (right). $(a, b, c) \mathrm{Ar} / \mathrm{Ar}$ age determination of early acidic rocks (after Troll et al., 2008). (a) Isochron derived from analysis of 20 single crystals separated from the early Rum rhyodacite. Note the high mean square weighted deviation (MSWD) indicating more than one age population is present amongst the sampled crystals. (b) Frequency distribution of crystal ages. The main peak at 60.33 is probably the eruption age of the early rhyodacite. Two older groups of crystals appear to be present, represented by the two shoulders to the right of the main peak. (c) Simplified age framework for Rum. If older 'xenocrysts' in the rhyodacite are discarded, a duration for the lifespan of the Rum volcano can be derived. The Rum volcano was probably short lived $(<1$ m.y.), as were other volcanoes in the province (e.g. Hamilton et al., 1998).
(59.98 $\pm 0.24 \mathrm{Ma}$; Chambers et al., 2005) that rests on the Western Granite (Fig. 25). These lavas were erupted during rapid subaerial erosion of the Rum centre and are derived from the younger Skye Centre to the North (see Troll et al., 2008). Igneous activity at Rum and elsewhere in northwest Scotland was almost entirely restricted to the Palaeogene but a study by Dobson et al. (2010) of apatite fission tracks in e.g. the Western
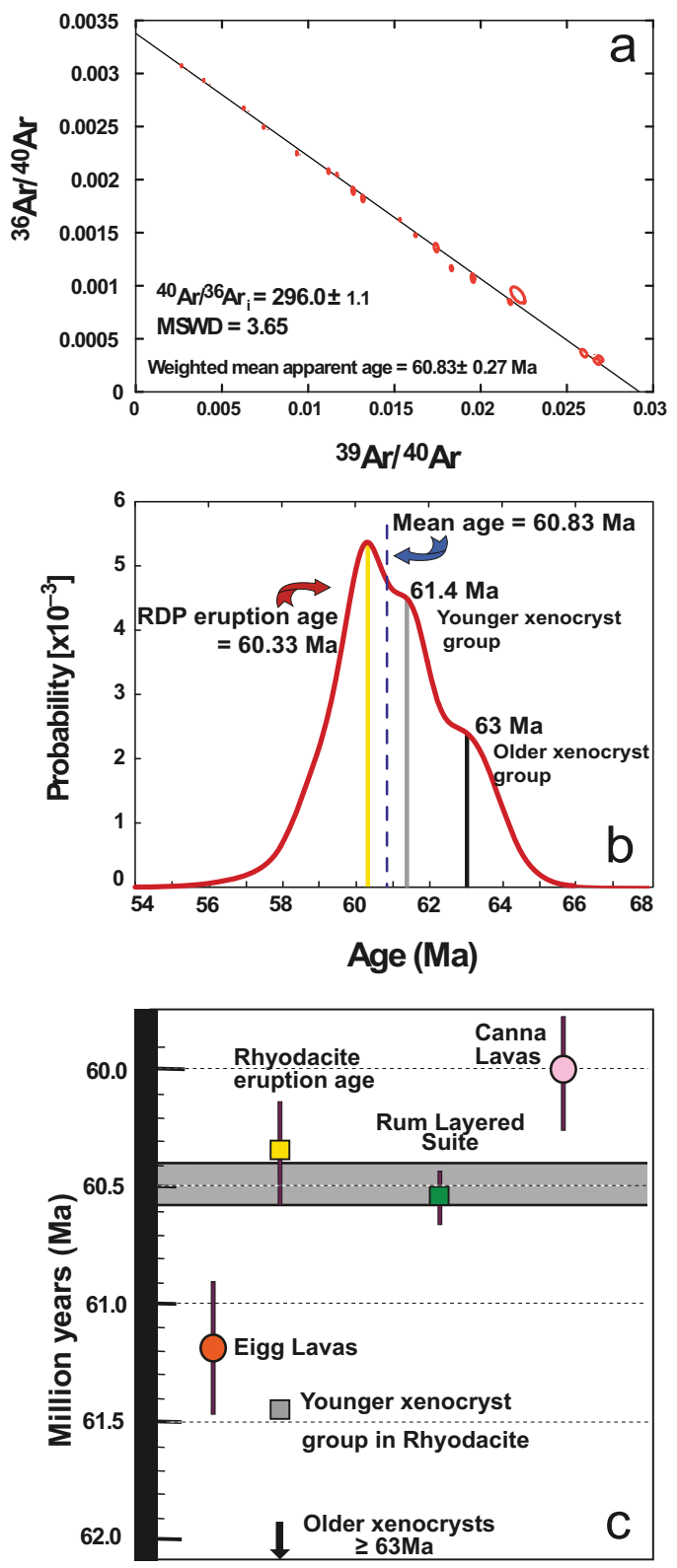

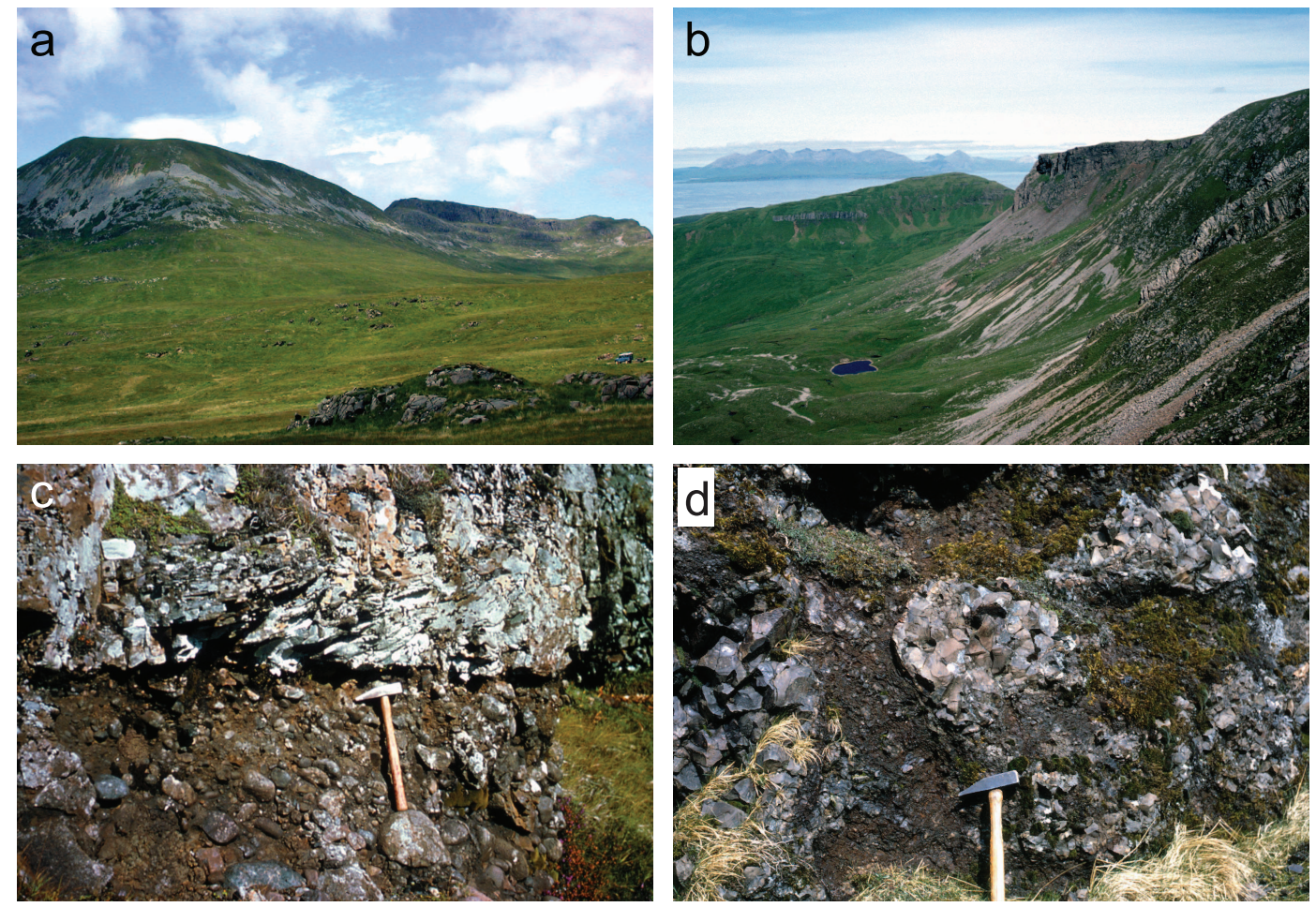

Fig. 25. The Canna Lava Formation in western Rum. (a) Pale-coloured outcrops and scree of the Western Granite on Ard Nev (left distance) and Orval (right distance). On Orval, basaltic hawaiite lavas of the Orval Member (Canna Lava Formation) form an unconformable cap to the granite. Peridotite of the Central Intrusion crops out in the foreground. (b) Western Granite crags (right) on Orval, overlain by later lavas of the Canna Lava Formation. Further lavas form the middle-distance hill, Fionchra, where they overlie Torridonian sandstone. The pale crags and talus in the foreground are in the Western Granite. The gabbro Cuillin hills of the Skye Central Complex are seen in the far distance. (c) Inter-lava fluviatile conglomerate containing clasts derived from the Rum Central Complex and surroundings, Canna Lava Formation, south side of Fionchra. Scale: hammer $\sim 30 \mathrm{~cm}$. (d) Pillow-lava textures in hyaloclastites at the northeast side of Fionchra, marking the base of the upper Fionchra Formation. Scale as in (c). Based on Emeleus (1997), with the permission of the British Geological Survey and Emeleus and Troll (2008).

granite has shown that the region underwent a 'reheating event' at $\sim 45-50 \mathrm{Ma}$, possibly caused by hitherto unrecognized small-volume intrusions which rejuvenated the hydrothermal systems. Notably, an Ar/Ar age of 45.2 \pm 0.2 Ma has been obtained from the monchiquite dyke at Loch Roag on Harris, in the Outer Hebrides (Faithfull et al., 2012), providing a potential clue to the cause of this reheating.

\section{Outlook}

Rum has been serving the petrology community as an exceptional natural laboratory for well over 50 years and its relatively small size and relatively short life time may give it distinct advantages over the larger and longer-lived classic layered intrusions in the study of magmatic processes (e.g. Bushveld or Stillwater). This realization is most relevant when attempting to decipher the detailed history of an intrusion because post-magmatic processes may have modified and even obliterated evidence from the earliest events, thus creating a large degree of 'uncertainty'. The rapid evolution of events that is traceable on Rum, together with the evidence for rapid cooling, probably provided a setting that allows the capture of a somewhat more complete picture. These advantages, together with the ever improving accessibility, 
make Rum a prime target for future investigations and a series of topics is foreseen that will probably stimulate researchers in the next decade or two.

Future efforts will naturally drive work on the Ultrabasic Layered Suite as numerous structures and textures found in rocks of the Layered Suite closely mimic those present in clastic sedimentary rocks, leading to their interpretation as the products of large-scale crystal settling in a magma chamber (e.g. Wager et al., 1960; Wager and Brown, 1968; LeMaitre, 2002), an origin long and increasingly contested (e.g.; McBirney and Noyes, 1979; O'Driscoll et al., 2007b; Holness, 2007; Latypov et al., 2013). The significant effects of post-magmatic processes cannot be questioned and may be widespread and a large-scale phenomenon, as with peridotite replacement of layered troctolites in the Central Intrusion (e.g. Fig. 16a,b), while structures interpreted traditionally in clastic sedimentological terms are also common (e.g. Figs 13b, $d, 14 b$, $19 a, b)$. Amongst the most contested outcrops are those of the 'Wavy Horizon' (Figs 17, 18), where the views of Bédard et al. (1988), Holness (2007) and Holness et al. (2007) differ radically from those of Young and Donaldson (1985) who advocated a 'sedimentological' explanation for the features, an interpretation also favoured by Volker and Upton $(1990,1991)$ for similar structures in the layered rocks on Trollaval. The controversial Wavy Horizon has most recently been interpreted as a reaction front and other examples from Rum are cited (Holness et al., $2005,2007)$, underlining the potentially important role of migrating residual fluids in modifying and overprinting texture and composition in the Rum cumulate pile and perhaps even in cumulate rocks in general. As the conditions for sedimentary deposition vs. magma percolation and inter-mush crystallization could hardly be more different, there is a clear necessity for the reconciliation of these opposing interpretations.

Whereas much can still be learned from detailed petrological studies of the rocks in question, advances on a macro-scale are also anticipated, e.g. 3D-modelling, as has recently been employed at Ardnamurchan (Burchardt et al., 2013), will probably help to further develop the overall conceptual framework of Rum's evolution. The Central Intrusion, in particular, holds the key to a deeper understanding of magma chamber processes and provides a record of the fluid-dynamic activity in crustal magma reser- voirs. These aspects have a bearing on understanding the relative roles of magma replenishment and reservoir instability (Fig. 26) and a wealth of direct field evidence exists on Rum for both of these phenomena. A further fruitful field of study could thus come from a rigorous structural examination of the emplacement of the Central Intrusion of the Ultrabasic Layered Suite.

At the time of the peak activity of the Layered Suite, a considerable volcanic edifice, perhaps similar to that of e.g. the Katla volcano on Iceland, would have towered over the Rum Centre, but was subsequently lost due to rapid erosion. This 'missing Rum volcano' remains an enigma whose solution is required in order to complete the 'Rum story'. Promising avenues of investigation might be the locally numerous and varied xenoliths in the Layered Suite, some of which include former lava compositions (now metamorphosed) in the ELI (e.g. Faithfull, 1985). Alternatively, the basaltic pebbles in the conglomerates of the younger lavas in northwest Rum (Fig. 25) (Emeleus, 1985, table 2) may present another possibility and it remains to be seen if these are chemically sufficiently distinct to help resolve this aspect of Rum's geological history from other events (e.g. Eigg or Canna lavas). A fuller geochemical assessment will probably also be a major area of investigation on Rum, for example a complete isotopic characterization of all major units and the exact evaluation of temporal variations in the recorded values. At present, a haze of 'parental' $v s$. 'crustal' ideas are represented in the literature and the effect of 'secondary processes' has not always been evaluated rigorously when 'reading' isotopic data.

The economic importance of chrome, sulfide and Pt-group element mineralization hardly needs stressing and the recognition that the Rum chromitite seams formed mostly in situ, arising from the examination of field relationships, mineralogy and texture (e.g. Latypov et al., 2013) needs to be further tested as it may have fundamental implications for the origins of chromitites and associated Pt-group element deposits in general.

Lastly, as has been shown over the last decade or so, advances in petrological and geochemical techniques will permit major leaps forward, such as the work by Tepley and Davidson (2003) using crystal-isotope stratigraphy, the detailed work on dihedral angles by Holness and co-workers (e.g. 


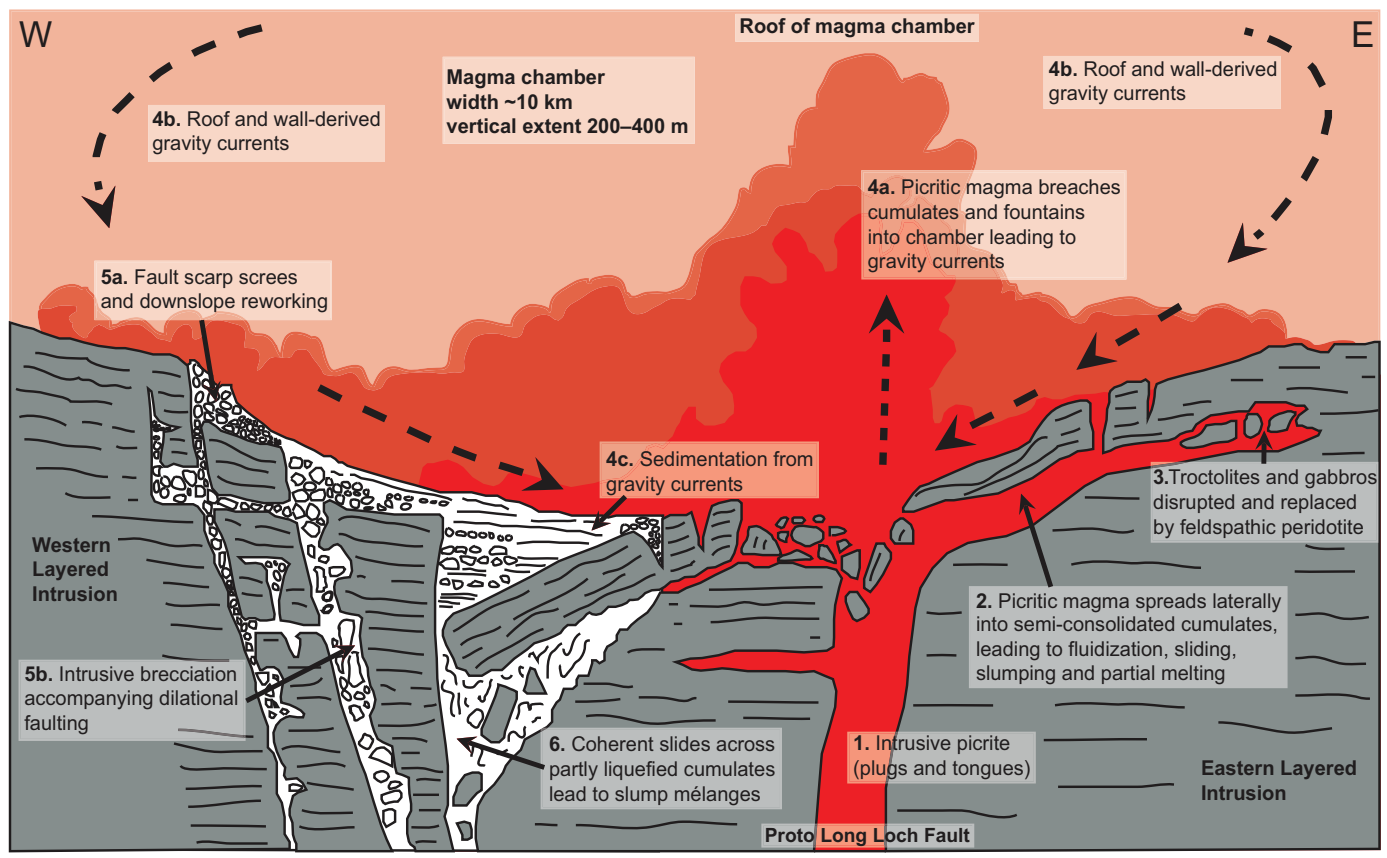

Fig. 26. Schematic representation of possible events leading to the formation of the Central Intrusion. Periodic replenishments of picritic magma (1) rejuvenated the magma chamber causing sliding and slumping and (2) intruded laterally into earlier cumulates leading to partial melting and cumulate recycling (3). Magma fountaining into the chamber (4a) flows off the roof and down the sides as crystal-laden, gravity-driven currents (4b), dislodging crystal mushes as they move, then spread across the floor, reworking cumulate debris and depositing this material and primary crystals on the floor (4c). Movement on faults was accompanied by magma injection, thermal erosion of earlier rocks, fragmentation to form breccia zones (5a), and dilation by intrusive brecciation of wall cumulates (5b). Slides of coherent blocks of cumulate across partly liquefied cumulate led to spectacular slump mélanges (6). Based on Emeleus and Bell (2005), with the permission of the British Geological Survey.

Holness et al. 2005, 2007, 2012a), or that on CSD by e.g. O'Driscoll et al. (2007a).

To clarify our knowledge and understanding on e.g. cumulus vs. post-cumulus processes, on magma-tectonic $v s$. fluid-dynamic processes, on sill-like vs. large crustal chambers, as well as on the style and frequency of small intrusive pulses vs. slowly accumulating macro-units, Rum will provide a 'test-bed' for these ideas and entertain and challenge petrologists and geochemists for many years to come. Work on many of the above aspects is either already on the way or will probably grow into serious efforts over the coming years by new researchers that are keen to work on Rum as well as established research teams with a 'track record' on the island. It can therefore be expected that Rum will continue to be a major source of inspiration, intrigue and inquisitive investigation for several future generations of researchers. We have only now started to understand the basic principles that define the geological history and evolution of Rum, which, in turn, provides an unparalleled opportunity for further detailed advances in research on Rum's geology and on magmatic processes in the most general sense.

\section{Acknowledgements}

Rum is the United Kingdom's largest National Nature Reserve, managed by Scottish Natural Heritage (SNH) and formerly by the Nature Conservancy Council. For more than 50 years a succession of Chief Wardens and Reserve Managers and their staff have facilitated scientific research on the island and they are owed a considerable debt of gratitude for their help and encouragement not least for the support given to the many undergraduates who have undertaken thesis mapping on Rum, thereby adding greatly to 
our knowledge. The authors are indebted to these organisations for permission to work on Rum and to their staff for their help and encouragement over many years. In recent years, the authors work on Rum also benefitted greatly from discussions on and off the field with B. Bell, S. Burchardt, C.H. Donaldson, E. Donoghue, M. Holness, E.P. Holohan, C. Jennings, D. Jerram, B. O'Driscoll, R. Mayer, G.R. Nicoll and B. Upton. The authors are indebted to E.P. Holohan, T. Mattsson, G.R. Nicoll, P. Nicolls, K. Pedroza and S. Roopnarain for valuable help with the photomicrographs and compilations of illustrative material. The images used in Figs $1 a, b, 2 a, b, 3 a, b, 4 a, 5 a, 7 a, 9 b, d$, $11 a, b, e, g, h, 13 b, d, f, 14 a, b, d, 16 a, 19 a, 20 a$, $25 a, b, c$ and 26 are reproduced with the permission of the Edinburgh Geological Society (Emeleus and Troll, 2008). The authors thank S. Burchardt for supplying Figs $9 a, 11 d, f, 13 e$ and $14 c$ ), G.R. Nicoll for supplying Figs $2 a, b$ and $9 b$, E. Donoghue for Fig. $4 b$ and E.P. Holohan for the basis of Fig. $3 a, b$. R. Meyer provided the data for Fig. 10a,b,c, M. Holness for Fig. 17a,b and B. O'Driscoll for Figs 21a,b, 23a,b,c). The late R.H. Hunter and M. Cheadle compiled the original concept for Fig. 26. Copyright material derived from several publications is acknowledged with the image captions. Thorough and constructive reviews by Jean Bédard, Marian Holness and Brian O'Driscoll are gratefully acknowledged. V.R. Troll acknowledges Science Foundation Ireland (SFI), the Royal Irish Academy (RIA) and the Swedish Science Foundation (VR) for generous financial support. C.H. Emeleus is indebted to Durham University for the continued use of facilities.

\section{References}

Bailey, E.B. (1945) Tertiary igneous tectonics of Rhum (Inner Hebrides). Quarterly Journal of the Geological Society, London, 100, 165-191.

Bédard, J.H., Sparks, R.S.J., Renner, R., Cheadle, M.J. and Hallworth, M.A. (1988) Peridotite sills and metasomatic gabbros in the Eastern Layered Series of the Rhum complex. Journal of the Geological Society, London, 145, 207-224.

Black, G.P. (1952) The age relationship of the granophyre and basalt of Orval, Isle of Rhum. Geological Magazine, 89, 106-112.

Blake, D.H., Elwell, R.W.D., Skelhorn, R.R. and Walker, G.P.L. (1965) Some relationships resulting from the intimate association of acid and basic magmas. Quarterly Journal of the Geological
Society, London, 121, 31-49.

British Geological Survey (1994) Rum. Scotland Sheet 60. Solid and Drift Geology. 1:50,000. British Geological Survey, Keyworth, Nottingham, UK.

Brothers, R.N. (1964) Petrofabric analyses of Rhum and Skaergaard rocks. Journal of Petrology, 5, 255-274.

Brown, D.J., Holohan, E.P. and Bell, B.R. (2009) Sedimentary and volcano-tectonic processes in the British Palaeogene Igneous Province: a review. Geological Magazine, 146, 326-352.

Brown, G.M. (1956) The layered ultrabasic rocks of Rhum, Inner Hebrides. Philosophical Transactions of the Royal Society of London, 24B, 1-53.

Brown, P.E., Chambers, A.D. and Becker, S.M. (1986) A large soft-sediment fold in the Lilloise Intrusion, East Greenland. Pp 125-144 in: Origins of Igneous Layering (I. Parsons, editor). NATO ASI Series, Series C: Mathematical and Physical Sciences, Vol. 186. Kluwer Academic, Dordrecht, The Netherlands.

Burchardt, S., Troll, V.R., Mathieu, L., Emeleus, C.H. and Donaldson, C.H. (2013) Ardnamurchan 3D cone-sheet architecture explained by a single elongate magma chamber. Scientific reports, doi:10.1038/srep02891.

Butcher, A.R., Young, I.M. and Faithfull, J.W. (1985) Finger structures in the Rhum Complex. Geological Magazine, 122, 491-502.

Butcher, A.R., Pirrie, D., Prichard, H.M. and Fisher, P. (1999) Platinum-group mineralization in the Rum layered intrusion, Scottish Hebrides. Journal of the Geological Society, London, 131, 931-944.

Chambers, L.M., Pringle, M.S. and Parrish, R.R. (2005) Rapid formation of the Small Isles igneous centre constrained by precise ${ }^{40} \mathrm{Ar} /{ }^{39} \mathrm{Ar}$ and U-Pb ages. Lithos, 79, 367-384.

Collinson, J.D. and Thompson, D.B. (1982) Sedimentary Structures. George Allen \& Unwin, London, 194 pp.

Dickin, A.P. and Jones, N.W. (1983) Isotopic evidence for the age and origin of pitchstones and felsites, Isle of Eigg, NW Scotland. Journal of the Geological Society, London, 140, 691-700.

Dobson, K.J., Stuart, F.M. and Dempster, T.C. (2010) Constraining the post-emplacement evolution of the Hebridean Igneous Province (HIP) using low-temperature thermochronology: how long has the HIP been cool? Journal of the Geological Society, London, 167, 973-984.

Donaldson, C.H., Drever, H.I. and Johnston, R. (1973) Crystallization of poikilo-macro-spherulitic feldspar in a Rhum peridotite. Nature, Physical Sciences, 243, 69-70.

Donaldson, C.H., Troll, V.R. and Emeleus, C.H. (2001) Felsites and breccias in the Northern Marginal Zone of the Rum Central Complex: changing views, $c$. 1900-2000. Proceedings of the Yorkshire Geological Society, 53, 167-175. 
Dunham, A.C. (1965) A new type of banding in ultrabasic rocks from central Rhum, Inverrness-shire, Scotland. American Mineralogist, 50, 1410-1420.

Dunham, A.C. (1968) The felsites, granophyre, explosion breccias and tuffisites of the north-eastern margin of the Tertiary igneous complex of Rhum, Inverness-shire, Scotland. Quarterly Journal of the Geological Society, London, 123, 327-352.

Elias, R.T. (1989) The origin of cyclic layering in the Eastern Layered Series of the Rhum intrusion. Geological Society of London Newsletter, 18, 38.

Emeleus, C.H. (1985) The Tertiary lavas and sediments of northwest Rhum, Inner Hebrides. Geological Magazine, 122, 419-437.

Emeleus, C.H. (1997) Geology of Rum and the adjacent islands. Memoir of the British Geological Survey, Sheet 60 (Scotland). British Geological Survey, Keyworth, Notingham, UK.

Emeleus, C.H. and Bell, B.R. (2005) British Regional Geology: the Palaeogene volcanic districts of Scotland (Fourth Edition). British Geological Survey, Keyworth, Nottingham, UK.

Emeleus, C.H. and Troll, V.R. (2008) A geological excursion guide to Rum: the Palaeocene igneous rocks of the Isle of Rum, Inner Hebrides. Edinburgh Geological Society, Edinburgh.

Emeleus, C.H. and Troll, V.R. (2011) Recent research developments on the Isle of Rum, NW Scotland. Geology Today, 27, 184-192.

Emeleus, C.H., Cheadle, M.J., Hunter, R.H., Upton, B.G.J. and Wadsworth, W.J. (1996) The Rum Layered Suite. Pp. 403-440 in: Layered Igneous Rocks (R.G. Cawthorn, editor). Elsevier, Amsterdam.

Faithfull, J.W. (1985) The Lower Eastern Layered Series of Rhum. Geological Magazine, 122, 459-468.

Faithfull, J.W., Timmerman, M.J., Upton, B.G.J. and Rumsey, M.S. (2012) Mid-Eocene renewal of magmatism in NW Scotland: the Loch Roag dyke, Outer Hebrides. Journal of the Geological Society, London, 169, 115-118.

Geldmacher, J., Troll, V.R., Emeleus, C.H. and Donaldson, C.H. (2002) Pb-isotope evidence for contrasting crustal contamination of primitive to evolved magmas from Ardnamurchan and Rhum: implications for the structure of the underlying crust. Scottish Journal of Geology, 38, 55-61.

Goodenough, K., Jerram, D.J., Emeleus, C.H. and Troll, V.R. (2008) Golden Rum: understanding the Forbidden Isles. Geoscientist, 18, 22-24.

Geikie, A. (1897) The Ancient Volcanoes of Great Britain. 2 volumes. Macmillan, London.

Hamilton, M.A., Pearson, D.G., Thompson, R.N., Kelley, S.P. and Emeleus, C.H. (1998) Rapid eruption of the Skye lavas inferred from precise
$\mathrm{U}-\mathrm{Pb}$ and Ar-Ar dating of the Rum and Cuillin plutonic complexes. Nature, 394, 260-263.

Harker, A. (1908) The geology of the Small Isles of Inverness-shire. Memoirs of the Geological Survey: Scotland, Sheet 60. British Geological Survey, Keyworth, Nottingham, UK.

Holness, M. (1999) Contact metamorphism and anatexis of Torridonian arkose by minor intrusions of the Rum Igneous Complex, Inner Hebrides, Scotland. Geological Magazine, 136, 527-542.

Holness, M.B. (2002) Spherulitic textures formed during crystallization of partially melted arkose, Rum, Scotland. Geological Magazine, 139, 651-663.

Holness, M.B. (2005) Spatial constraints on magma chamber events from textural observations on cumulates: the Rum Layered Intrusion, Scotland. Journal of Petrology, 46, 1585-1601.

Holness, M.B. (2007) Textural immaturity of cumulates as an indicator of magma chamber processes: infiltration and crystal accumulation in the Rum layered suite. Journal of the Geological Society, London, 164, 529-539.

Holness, M.B. and Isherwood, C.E. (2003) The aureole of the Rum Tertiary Igneous Complex, Scotland. Journal of the Geological Society, London, 160, $15-27$.

Holness, M.B. and Winpenny, B. (2009) The Unit 12 allivalite, Eastern Layered Intrusion, Isle of Rum: a textural and geochemical study of an open-system magma chamber. Geological Magazine, 146, 437-460.

Holness, M.B., Cheadle, M.J. and McKenzie, D.F. (2005) The use of changes in dihedral angle to decode late-stage evolution in cumulates. Journal of Petrology, 46, 1565-1583.

Holness, M.B., Hallworth, M.A., Woods, A. and Sides, R.E. (2007) Infiltration metasomatism of cumulates by intrusive magma replenishments: the Wavy Horizon, Isle of Rum, Scotland. Journal of Petrology, 48, 563-587.

Holness, M.B., Humphreys, M.C.S., Sides, R., Helz, R.T. and Tegner, C. (2012a) Towards an understanding of disequilibrium dihedral angles in mafic rocks. Journal of Geophysical Research, 117, 1-31.

Holness, M.B., Sides, R., Prior, D.J., Cheadle, M.J. and Upton, B.G.J. (2012b) The peridotite plugs of Rum: crystal settling and fabric development in magma conduits. Lithos, 134, 23-40.

Holohan, E.P., Troll, V.R. and Emeleus, C.H. (2008) The Southern Mountains and Dibidil. Pp. 97-140 in: A geological excursion guide to Rum: The Paleocene igneous rocks of the Isle of Rum, Inner Hebrides (C.H. Emeleus, and V.R. Troll, editors). Edinburgh Geological Society, Edinburgh.

Holohan, E.P., Troll, V.R., Errington, M., Donaldson, C.H., Nicoll, G.R. and Emeleus, C.H. (2009) The 
Southern Mountains Zone, Isle of Rum, Scotland: volcanic and sedimentary processes upon an uplifted and subsided magma chamber roof. Geological Magazine, 146, 400-418.

Hughes, C.J. (1960) The Southern Mountains Igneous Complex, Isle of Rhum. Quarterly Journal of the Geological Society, London, 116, 111-138.

Huppert, E.H. and Sparks, R.S.J. (1985) Cooling and contamination of mafic and ultramafic magma during ascent through continental crust. Earth and Planetary Science Letters, 74, 371-386.

Irvine, T. (1980) Magmatic infiltration, double diffusive fractional crystallization and adcumulus growth in the Muskox and other layered intrusions. Pp. 325-383 in: Physics of Magmatic Processes (R.B. Hargreaves, editor). Princeton University Press, New Jersey, USA.

Judd, J.W. (1874) The Secondary rocks of Scotland. Second paper. On the ancient volcanoes of the Highlands and the relations of their products to the Mesozoic Strata. Quarterly Journal of the Geological Society, London, 30, 220-301.

Lacasse, C., Sigurdsson, H., Johannesson, H., Paterne, M. and Carey, S. (1995) Source of ash zone 1 in the North Atlantic. Bulletin of Volcanology, 57, 18-32.

Lacasse, C., Sigurdsson, H., Carey, S.N., Johannesson H., Thomas, L.E. and Rogers, N.W. (2007) Bimodal volcanism at the Katla subglacial caldera, Iceland: insight into the geochemistry and petrogenesis of rhyolitic magmas. Bulletin of Volcanology. 69, 373-399.

Larsen, G. (2000) Holocene eruptions within the Katla volcanic system, south Iceland: characteristics and environmental impact. Jökull, 49, 1-28.

Latypov, R., O'Driscoll, B. and Lavrenchuk, A. (2013) Towards a model for the in situ origin of PGE reefs in layered intrusions: insights from chromitite seams of the Rum Eastern Layered Intrusion, Scotland. Contributions to Mineralogy and Petrology, 166, 309-327.

LeMaitre, R.W. (2002) Igneous Rocks. A Classification and Glossary of Terms (2 ${ }^{\text {nd }}$ Edition). Cambridge University Press, Cambridge, UK, pp 236.

McBirney, A.R. and Noyes, R.M. (1979) Crystallisation and layering in the Skaergaard intrusion. Journal of Petrology, 38, 487-554.

McClurg, J. (1982) Petrology and evolution of the northern part of the Rhum ultrabasic complex. Unpublished $\mathrm{PhD}$ thesis, University of Edinburgh, Edinburgh.

Meyer, R., Nicoll, G.R., Hertogen, J., Troll, V.R., Ellam, R.M. and Emeleus, C.H. (2009) Trace element and isotope constraints on crustal anatexis by upwelling mantle melts in the North Atlantic Igneous Province: an example from the Isle of Rum, Scotland. Geological Magazine, 146, 382-399.
Nicoll, G.R. (2007) Evolution and crustal contamination of igneous rocks from the Palaeocene Volcanic District of North-West Scotland. Unpublished PhD Thesis, Trinity College, Dublin.

Nicoll, G.R., Holness, M.B., Troll, V.R., Holohan, E.P., Emeleus, C.H. and Chew, D. (2009) Early mafic magmatism and crustal anatexis on the Isle of Rum: evidence from the Am Màm intrusion breccias. Geological Magazine, 146, 368-381.

O'Driscoll, B., Donaldson, C.H., Troll, V.R., Jerram, D.J. and Emeleus, C.H. (2007a) An origin for harrisitic and granular olivine in the Rum Layered Suite, NW Scotland: a Crystal Size Distribution study. Journal of Petrology, 48, 253-270.

O'Driscoll, B., Hargreaves, R.B., Emeleus, C.H., Troll, V.R., Donaldson, C.H. and Reavy, R.J. (2007b). Magmatic lineations inferred from anisotropy of magnetic susceptibility fabrics in Units 8, 9 and 10 of the Rhum Eastern Layered Series, Scotland. Lithos, 98, 27-44.

O'Driscoll, B., Day, J.M.D., Daly, J.S., Walker, R.J. and McDonough, W.F. (2009a) Rhenium-Osmium isotopes and platinum-group elements in the Rum Layered Suite, Scotland: implications for Cr-spinel seam formation and the composition of the Iceland mantle anomaly. Earth and Planetary Science Letters, 286, 41-61.

O'Driscoll, B., Donaldson, C.H., Daly, J.S. and, Emeleus, C.H. (2009b) The roles of melt infiltration and cumulate assimilation in the formation of anorthosites and a Cr-spinel seam in the Rum Eastern Layered Intrusion. Lithos, 111, 6-20.

O'Driscoll, B., Emeleus, C.H., Donaldson, C.H. and Daly, J.S. (2010) Cr-spinel petrogenesis in the Rum Layered Suite, NW Scotland: cumulate assimilation and in situ crystallization in a deforming crystal mush. Journal of Petrology, 51, 1171-1201.

Óladóttir, B.A., Larsen, G., Thordarson, T. and Sigmarsson, O. (2005) The Katla volcano SIceland: Holocene tephra stratigraphy and eruption frequency, Jökull, 55, 53-74.

Óladóttir, B.A., Sigmarsson, O., Larsen, G. and Thordarson, T. (2008) Katla volcano, Iceland: magma composition, dynamics and eruption frequency as recorded by Holocene tephra layers. Bulletin of Volcanology, 70, 475-493.

Petronis, M.S., O'Driscoll, B., Troll, V.R., Emeleus, C.H. and Geissman, J.W. (2009) Palaeomagnetic and anisotropy of magnetic susceptibility data bearing on the emplacement of the Western Granite, Isle of Rum, Scotland. Geological Magazine, 146, 419-436.

Power, M.R., Pirrie, D. and Andersen, J.C.O. (2000a) Testing the validity of chrome spinel as a provenance and petrogenetic indicator. Geology, 28, 1027-1030. Power, M.R., Pirrie, D., Andersen, J.C.O. and Butcher, 


\section{RUM IGNEOUS COMPLEX}

A.R. (2000b). Stratigraphic distribution of platinumgroup elements in the Eastern Layered Series, Rum, Scotland. Mineralium Deposita, 35, 762-775.

Power, M.R., Pirrie, D. and Andersen, J.C.O. (2003) Diversity of platinum-group element mineralization styles in the North Atlantic Igneous Province: new evidence from Rum, U.K. Geological Magazine, 144, 499-512.

Renner, R. and Palacz, Z.A. (1987) Basaltic replenishment of the Rhum magma chamber: evidence from Unit 14. Journal of the Geological Society, London, 144, 961-970.

Scottish Natural Heritage (1994) Rum - Solid Geology, 1:20,000. Scottish Natural Heritage, Inverness, UK.

Sparks, R.S.J., Huppert, H.E., Kerr, R.C., McKenzie, D.P. and Tait, S.R. (1985) Postcumulus processes in layered intrusions. Geological Magazine, 122, $558-568$.

Tepley, F.J. III and Davidson, J.P. (2003) Mineral-scale Sr-isotope constraints on magma evolution and magma chamber dynamics in the Rum layered intrusion, Scotland. Contributions to Mineralogy and Petrology, 145, 628-641.

Tilley, C.E. (1944) A note on the gneisses of Rum. Geological Magazine, 89, 129-131.

Troll, V.R., Emeleus, C.H. and Donaldson, C.H. (2000) Caldera formation in the Rum Central Igneous Complex, Scotland. Bulletin of Volcanology, 62, $301-317$.

Troll, V.R., Donaldson, C.H. and Emeleus, C.H. (2004) Pre-eruptive magma mixing in ash-flow deposits in the Tertiary Rum Igneous Centre, Scotland. Contributions to Mineralogy and Petrology, 147, 722-739.

Troll, V.R., Nicoll, G.R., Donaldson, C.H. and Emeleus, C.H. (2008) Dating the onset of volcanism at the Rum Igneous Centre, NW Scotland. Journal of the Geological Society, London, 165, 651-659.

Upton, B.G.J., Skovgaard, A.C., McClurg, J.E., Kirstein, L., Cheadle, M.J., Emeleus, C.H., Wadsworth, W.J. and Fallick, A.E. (2002) Picritic magmas in the Rum ultramafic complex, Scotland. Geological Magazine, 139, 437-452.

Volker, J.A. and Upton, B.G.J. (1990) The structure and petrogenesis of the Trallval and Ruinsival area of the Rhum ultrabasic complex. Transactions of the Royal Society of Edinburgh: Earth Sciences, 81, 69-88.

Volker, J.A. and Upton, B.G.J. (1991) Reply to comments by J.H. Bédard and R.S.J. Sparks. Transactions of the Royal Society of Edinburgh: Earth Sciences, 82, 391.

Wadsworth, W.J. (1961) The layered ultrabasic rocks of south-west Rhum, Inner Hebrides. Philosophical Transactions of the Royal Society of London. 244B, $21-64$.

Wadsworth, W.J. (1985) Layered intrusions - a fluid situation? Geology Today, 2, 50-54.

Wadsworth, W.J. (1992) Ultrabasic igneous breccias of the Long Loch area, Isle of Rhum. Scottish Journal of Geology, 28, 103-113.

Wager, L.R. and Brown, G.M. (1968) Layered Igneous Rock. Oliver and Boyd, Edinburgh.

Wager, L.R., Brown, G.M. and Wadsworth, J.W. (1960) Types of igneous cumulates. Journal of Petrology, $\mathbf{1}$, $73-85$.

Williamson, I.T. and Bell, B.R. (1994) The Palaeocene lava field of west-central Skye, Scotland: stratigraphy, palaeogeography and structure. Transactions of the Royal Society of Edinburgh: Earth Sciences, 89, 39-75.

Worrell, L.M., Cheadle, M.J., Coogan, L.A., Prior, D.J., Toplis, M.J. and Wheeler, J. (2003) Multidisciplinary approach to understanding the origin of peridotite cumulates. American Geophysical Union, Fall Meeting 2003, San Francisco, USA, Abstract \#V11F-02. American Geophysical Union, Washington, USA.

Young, I.M. and Donaldson, C.H. (1985) Formation of granular-textured layers and laminae within the Rhum crystal pile. Geological Magazine, 122, 519-528. 